\title{
Pteridophytes as ecological indicators: an overview ${ }^{1}$
}

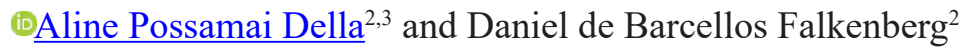

Received: 25 May 2018; accepted: 10 December 2018

How to cite: Della, A.P. \& Falkenberg, D.B. 2019. Pteridophytes as ecological indicators: an overview. Hoehnea 46: e522018. http://dx.doi.org/10.1590/2236-8906-52/2018.

\begin{abstract}
Pteridophytes as ecological indicators: an overview). The pteridophytes present a great but poorly explored potential as ecological indicators (EIs), shown only in some sparse studies. Therefore, to analyze this potential, we reviewed published articles, websites, or books with pteridophytes as EIs, searching on five scholar databases and also on Google. We selected 134 studies, conducted in all continents (118 in mainland areas and 16 in islands). Brazil is the country with the highest number of studies $(\mathrm{N}=33)$. In general, several species were considered as EIs in a given study, not only a single. The use of Pteridophytes in these works was classified in seven different types: a) classification of vegetation, soils, environments, and ecosystems $(N=65), b)$ environmental integrity (or quality) $(N=21), c)$ disturbance $(N=17), d)$ regeneration/restoration of habitats and/or ecosystems $(\mathrm{N}=10)$, e) climate changes $(\mathrm{N}=10)$, f) contamination of air, soil, or water $(\mathrm{N}=14)$, and $\mathrm{g})$ association with other groups of organisms $(\mathrm{N}=12)$. The vast majority of these studies merely hypothesized the potential use of the Pteridophytes as EIs, with few presenting helpful criteria for the selection of EIs. Although there is an increasing recognition of the potential use of Pteridophytes as EIs, a more in-depth discussion about the criteria for selecting Pteridophytes as indicators and the real uses of such plants is needed.

Keywords: ferns, lycophytes, types of indication, applied ecology, environmental conservation, plant-environment relationships, bioindicators, plant uses.
\end{abstract}

RESUMO - (Pteridófitas como indicadores ecológicos: uma visão geral). As pteridófitas apresentam grande potencial como indicadores ecológicos (EIs), mas pouco explorado, mostrado apenas em trabalhos esparsos. Portanto, para analisar esse potencial, revisamos artigos publicados, sites ou livros com pteridófitas como EIs, realizando buscas em cinco bases de dados acadêmicas e no Google. Selecionamos 134 estudos, feitos em todos os continentes (118 em áreas continentais e 16 em ilhas). O Brasil é o país com maior número de estudos $(\mathrm{N}=33)$. Em geral, várias espécies foram consideradas como EIs em cada estudo, não somente uma. O uso das pteridófitas nesses estudos foi classificado em sete tipos de indicação: a) classificação de vegetação, solos, ambientes e ecossistemas $(\mathrm{N}=65), b)$ integridade (ou qualidade) ambiental $(\mathrm{N}=21), \mathrm{c})$ perturbação $(\mathrm{N}=17), \mathrm{d})$ regeneração/restauração de habitats e/ou ecossistemas $(\mathrm{N}=10)$, e) mudanças climáticas $(\mathrm{N}=10)$, f) contaminação de ar, solo ou água $(\mathrm{N}=14)$ e g) associação com outros grupos de organismos $(\mathrm{N}=12)$. A maioria desses estudos apenas hipotetizou o potencial uso das pteridófitas como EIs, com poucos apresentando ou analisando critérios de seleção de EIs. Há crescente reconhecimento do potencial de uso das pteridófitas como EIs, mas faltam discussões sobre a escolha de critérios para selecionar pteridófitas indicadoras e sobre as reais utilizações dessas plantas.

Palavras-chave: licófitas, samambaias, tipos de indicação, ecologia aplicada, conservação ambiental, relações planta-ambiente, bioindicadores, usos de plantas

\section{Introduction}

Ecological indicators (EIs) are useful tools to link empirical results, models, and theories with environmental applications. They are broadly employed in the classification of environments and in the evaluation of natural and/or anthropic disturbance or stress (Niemi \& McDonald 2012, Siddig et al. 2016). One definition considers EIs as a species or group of species that readily reflects the abiotic or

1. Parte do Trabalho de Conclusão de Curso da primeira Autora

2. Universidade Federal de Santa Catarina, Centro de Ciências Biológicas, Departamento de Botânica, Laboratório de Sistemática de Plantas Vasculares, CEP 888040-900, Florianópolis, SC, Brasil

3. Corresponding author: alinepossamaidella@hotmail.com 
biotic state of an environment (McGeoch 1998, Dale \& Beyeler 2001, Heink \& Kowarik 2010a). This definition includes only species and/or group of them, but other taxonomic levels (family, genus) or still ecological attributes (as richness and diversity) could be adopted.

The EIs are often used because they are more easily measurable than other ecological variables of greater interest but difficult measurement (the indicandum, if only one, or the indicanda, if two or more), or when budget and time are restricted (Öster et al. 2008). The use of EIs is multiple as to indicate biotic and abiotic conditions, identify and monitor environmental changes (natural and/or caused by man), identify areas to conserve/restore or more favorable for agriculture, and to predict the distribution of other organisms (Sampson 1939, McGeoch 1998, Niemi \& McDonald 2012).

The choice of EIs is directly related to the purpose(s) of indication. For the selection of suitable and effective EIs, many criteria were proposed to minimize chances of spending time and resources studying taxa that are unlikely to be good indicators (McGeoch 1998, Heink \& Kowarik 2010b). We summarize criteria suggested by different studies in table 1 to check how they are or could be used for pteridophytes.

To select a good EI, four sets of these criteria must be evaluated. First, the economic and logistical suitability (including financial cost, time efficiency, and personnel requirements); followed by the analysis and interpretation efficiency (including the accurate correlation between indicator and indicandum, the capacity of be understandable, self-explanatory, and simplify the information); then the availability of ecological information (including distributional, reliability, representation, physical tolerance, response in function of natural or anthropogenic stress and enemies); and finally, the taxonomic knowledge (including ease of field identification to avoid collecting taxa that do not belong to the indicator group, and that inexperienced or non-experts can be trained quickly to support the studies).

In addition to establishing criteria, some further steps can be followed to select EIs. McGeoch (1998) proposes nine of them that, regardless of the objective of the indicator, might be considered (table 2). Throughout the selection process, one must have clarity about the objectives to use the EI, and of its temporal and spatial scales. The scale of indication is essential, since a local and transitory disturbance might not be able to be evaluated using regional or global scales. Thus, the objective of this selection is to identify an organism, or group of organisms, that reflects a particular abiotic or biotic characteristic on the interest scale. The sampling methods should be planned to identify relationships between the EIs and environmental or biotic variables of interest, as strong (significant) relations provide greater predictive values.

Pteridophytes are vascular plants without seeds currently with about 12,000 known species. They are from two phylogenetically distinct groups: the lycophytes (less than 1500 species) and the ferns (some 10,500 species) (PPG I 2016). They are widely distributed, from the tundra to tropical forests, being more diverse in the equatorial region (Tryon 1972, Tryon \& Tryon 1982, Moran 2008). Although lycophytes and ferns reach high frequency and abundance in humid forests, they also occur in dry environments, where some genera can be quite species-rich (Moran 2008). Locally pteridophytes are not randomly distributed, as their presence or absence reflects microhabitat characteristics, such as soil texture and fertility, atmospheric temperature and humidity, precipitation, and light intensity (Nóbrega et al. 2011, Patil et al. 2016). Hence the distribution of pteridophytes being strongly related with abiotic variables, this group presents a great potential as EI. In addition, a large number of genera or species are easily recognized in the field (Tuomisto \& Ruokolainen 1993, Salovaara et al. 2004).

Considering the great potential of lycophytes and ferns as EIs, the main objectives of this article are: (1) to compile available literature that mentions lycophytes and ferns as EIs, (2) to provide an overview of the current state of research and use of pteridophytes as EIs, (3) to identify the main research areas, criteria, methods, and target groups, and (4) to highlight needful prospects in the study and use of indicator pteridophytes.

\section{Material and Methods}

The bibliographic review was mainly concentrated on the search for scientific articles, but also scholar books, thesis, and websites treating the pteridophytes as EIs were included.

Search and selection strategy - The bibliographic research was carried out from October 2015 to 
Table 1. Criteria suggested by different authors for the selection of ecological indicators (EIs).

Criteria for selecting EIs

Have a relationship and/or accurate correlation between indicator and indicandum

Have feasibility for analysis and interpretation

Be understandable and simplify the information

Be as self-explanatory as possible (interpretation of EIs should not require advanced knowledge of subjects)

Be statistically analyzed

Be rare and threatened

Be a representative of critical components, functions, and processes

Have economic potential

Be politically relevant

Be relevant from the users' point of view

Be universal

Have efficient and effective cost (time, resource, personnel)

Be easily measurable

Have low variability in response

Have a convenient size that allows easy observation and collection

Be easily recognized in the field, thus avoiding the loss of time by collecting plants that do not belong to the indicator group

There should not be many species so that a person can learn to recognize them in the field

Have populations easily researched and manipulated so that the tests are logistically simple, and inexperienced students and non-professionals can be easily trained to help conduct the studies

Be relatively well-known taxonomically so that the identification isn't very difficult, and to have available taxonomic knowledge

Have abundant autoecological data (availability of ecological information) McGeoch (1998), Heink \& Kowarik (2010b)

Have key data (on environments of EIs) easily accessible and available at a reasonable cost

Have well-known biology and natural history, as well as enemies, physical tolerance, and to have known all stages of the life cycle

Be abundant

Have high species richness

Be easily sampled and classified

Have adequate representation in the sample

Sampling individuals are expendable

Facility and reliability of storage

Have enough species to show a wide range of ecological adaptations
Reference(s)

Heink \& Kowarik (2010b)

Heink \& Kowarik (2010b)

Heink \& Kowarik (2010b)

Alfsen \& Sæbø (1993)

Heink \& Kowarik (2010b)

Heink \& Kowarik (2010b)

McGeoch (1998)

Pearson (1994), Rodríguez et al. (1998), Kessler \& Bach (1999), Heink \& Kowarik (2010b)

Rapport \& Hildén (2013)

Heink \& Kowarik (2010b), Rapport \& Hildén (2013)

Heink \& Kowarik (2010b)

McGeoch (1998)

Dale \& Beyeler (2001)

Dale \& Beyeler (2001)

Tuomisto \& Ruokolainen (1998)

Tuomisto \& Ruokolainen (1998), Kessler \& Bach (1999)

Tuomisto \& Ruokolainen (1998)

Pearson (1994), Rodríguez et al. (1998), Kessler \& Bach (1999), Heink \& Kowarik (2010b)

Pearson (1994), McGeoch (1998), Rodríguez et al. (1998), Tuomisto \& Ruokolainen (1998), Kessler \& Bach (1999)

Alfsen \& Sæbø (1993)

Pearson (1994), McGeoch, (1998), Rodríguez et al. (1998), Kessler \& Bach (1999)

McGeoch (1998)

Dufrêne \& Legendre (1997)

McGeoch (1998), Heink \& Kowarik (2010b)

McGeoch (1998)

McGeoch (1998)

McGeoch (1998)

Tuomisto \& Ruokolainen (1998) 


\section{Table 1 (continuation)}

Criteria for selecting EIs

Wide range size and growth forms

Be representative of related and unrelated taxa

Show a well-defined response, this is, replace or can be replaced by other species

Be distributed across a wide range of regions and environments

Be a common plant in different types of forest, so that it is always found

At higher taxonomic levels (order, family, tribe, genera), occurring within a broad geographic range with various types of habitats

At lower taxonomic levels (species, subspecies), the specialization of each population within a habitat determines the sensitivity to habitat change

Have special habitat

Predictable spatial and temporal distribution to ensure long-term continuity Accumulate pollutants easily

Be able to provide continuous assessment over a wide range of stress

Have known responses to natural disturbance, anthropic stress, and changes over time

Distinguish between natural and man-made changes

Not to be used by humans

Be sensitive to changes (stresses) in the system, and respond in a predictable way

Be anticipatory (meaning an imminent change in the ecological system)

Predict changes that can be avoided by management actions

Have sufficient species that differ in habit requirements in relation to change when a forest is disturbed

Be integrative: the full set of EIs provides a measure of the coverage of key gradients in ecological systems (e.g., soils, vegetation types, temperature, etc)

Give the impression of the most important aspects of the state of an environment, but without being so broad (many individual EIs tend to disorganize the overview)
Reference(s)

McGeoch (1998), Kessler \& Bach (1999)

Pearson (1994), McGeoch (1998), Rodríguez

et al. (1998), Kessler \& Bach (1999)

McGeoch (1998)

Dufrêne \& Legendre (1997), McGeoch (1998), Kessler \& Bach (1999)

Tuomisto \& Ruokolainen (1998)

Pearson (1994), Rodríguez et al. (1998)

Pearson (1994), Rodríguez et al. (1998)

Kessler \& Bach (1999), Heink \& Kowarik (2010b)

McGeoch (1998)

McGeoch (1998)

McGeoch (1998)

Dale \& Beyeler (2001)

Alfsen \& Sæbø (1993), McGeoch (1998), Heink \& Kowarik (2010b)

Tuomisto \& Ruokolainen (1998)

Dale \& Beyeler (2001), Heink \& Kowarik (2010b)

Dale \& Beyeler (2001)

Dale \& Beyeler (2001)

Beukema \& Van Noordwijk (2004)

Dale \& Beyeler (2001)

Alfsen \& Sæbø (1993)

Table 2. Steps for establishing an ecological indicator (EI) (adapted from McGeoch 1998).

\begin{tabular}{ccc}
\hline & Steps & Description \\
\hline 1 & Determine broad objectives & Ecological indicators
\end{tabular}

To determine and be able to predict, using an EI: 1) the impact of

2 Refine objectives and clarify endpoint disturbance (or pollution, or habitat alteration, or climate change) on biota (communities, habitats, ecosystems), or 2) the responses of other taxa, or 3) the vegetation structure 
Table 2 (continuation)

\begin{tabular}{|c|c|c|}
\hline & Steps & Description \\
\hline 3 & $\begin{array}{l}\text { Select potential EI based on accepted a } \\
\text { priori suitability criteria }\end{array}$ & Select a species, higher level taxon, or assemblage \\
\hline 4 & Accumulate data on EI & $\begin{array}{l}\text { Determine the response of the EI to disturbance (or pollution, or habitat } \\
\text { alteration, or climate change); or search data about its presence or absence } \\
\text { with other taxa and its interactions with these species, or with vegetation } \\
\text { structure }\end{array}$ \\
\hline 5 & Collect quantitative relational data & $\begin{array}{c}\text { Measure levels of disturbance (or pollutant concentrations, or altered habitat } \\
\text { parameters, or climatic variables), or determine the diversity and richness of } \\
\text { other taxa of interest or of the vegetation structure }\end{array}$ \\
\hline 6 & $\begin{array}{l}\text { Establish statistically the relationship } \\
\text { between the EI and the relational data }\end{array}$ & $\begin{array}{l}\text { Establish the relationship between the disturbance (or the contamination } \\
\text { level, or habitat alteration, or climate change, or composition and abundance } \\
\text { of other taxa, or vegetation structure) and the EI }\end{array}$ \\
\hline 7 & $\begin{array}{l}\text { Based on the nature of the relationship, } \\
\text { either accept (preliminarily) or reject } \\
\text { the species, higher level taxon or } \\
\text { assemblage as an EI }\end{array}$ & $\begin{array}{l}\text { Are there significant correlations between the disturbance (or pollution, or } \\
\text { habitat alteration, or climate change, or diversity of other taxa, or parameters } \\
\text { of vegetation) and measured qualities of the EI? Yes: continue to step } 8 \text {. No: } \\
\text { repeat procedure from step } 3 \text {. }\end{array}$ \\
\hline 8 & $\begin{array}{l}\text { Establish the robustness of the EI by } \\
\text { developing and testing appropriate } \\
\text { hypotheses under different conditions }\end{array}$ & $\begin{array}{c}\text { H0: there is no significant relationship between the disturbance (or pollution, } \\
\text { or habitat alteration, or climate change, or other taxa, or vegetation) and } \\
\text { measured qualities of the EI in other areas or at different times }\end{array}$ \\
\hline 9 & $\begin{array}{l}\text { If the null hypotheses are rejected, make } \\
\text { specific recommendations, based on the } \\
\text { original objectives, for the use of the EI }\end{array}$ & $\begin{array}{l}\text { Use the EI to monitor and predict disturbance, or contamination, or integrity, } \\
\text { or climate change, or other taxa, or to classify communities, habitats, and } \\
\text { ecosystems }\end{array}$ \\
\hline
\end{tabular}

July 2017, in five scientific search engines: Scopus, ScienceDirect, PubMed, SciELO, and Google Scholar. The keywords used in the searches were: ferns, pteridophytes, and ecological indicator (in English, Portuguese, and Spanish). The results of these searches were checked for the title, and subsequently for the abstract and keywords. We selected and analyzed the papers that presented the following criteria:

Be published in peer-reviewed scientific journal, book, or thesis.

Be written in English, Portuguese, or Spanish (other languages as Chinese, French, and German were excluded).

Report species or ecological attributes of pteridophytes as EIs.

Be published as from 1980.

In addition, the references of the selected studies were verified, with potentially eligible papers also searched and analyzed, if they had the inclusion criteria and were electronically available for us. Searches were not limited to these databases. Using Google, we also checked websites, books, and monographs available online, using the same keywords. Thus, we selected a total of 122 articles, four websites, four monographs, and four book chapters, totaling 134 studies.

Data extraction and analyses - For each study selected, we extracted the following information: (a) country or countries where the study was carried out, (b) taxa or ecological attributes considered as EIs, (c) methodology and criteria utilized, and (d) results obtained.

As pteridophytes were tested or employed as EIs in a wide variety of objectives, we classified the studies with a similar purpose in different types of indication. The type of indication refers to the indicandum of an indicator, its usefulness, function, purpose of selection, and the possible use of the EI.

We consider the spatial scale of indication, at two levels of amplitude: regional or global. At the regional level, EIs hypothesized or were employed to indicate events (situations) with more restricted geographic distribution (city(ies), state(s), country(ies), and/or group of these). At the global level, they were applied to indicate events (situations) of wider distribution (continents or globe). 
We checked if studies included (or not) sampling and data collection in the field. For this, we classify them into two categories: as empirical (with their own data analyses) or as revisive. Empirical studies included data from fieldwork, or collected data from others and discussed the indication potential of the taxa. Revisive studies only cited results/information from previous studies without hypothesizing, arguing, or concluding about the use of certain taxa as EIs.

We examined if each study presented criteria of selection of EIs (such as those in table 1) and if its main objective was to establish/use pteridophytes as EIs. We also checked if there was a relationship between the indicator and the indicandum, and if there was a logical proposition of this relation. Finally, we verified if the studies used statistical tests, separating them into two groups: those that tested statistically the correlation of indicator and indicandum, and those which did not.

Conspectus of the selected studies - A total of 134 studies were published from 1980 to 2018 (table 3). Until the year 2000, an average of one paper with pteridophytes as EIs was published yearly. From then, there was an increase, especially this last decade to reach 16 papers in 2016 (figure 1). These studies were published in a wide variety of journals, but mostly in Ecological Indicators $(\mathrm{N}=9)$, Biodiversity and Conservation $(\mathrm{N}=7)$, and Biological Conservation ( $\mathrm{N}$ $=6$ ). Articles with pteridophytes as EIs were not found in other important conservation biology journals, such as Conservation Biology or Conservation Letters.

Studies with pteridophytes as EIs covered all continents but not equally: Africa $(\mathrm{N}=9)$, America $(\mathrm{N}=79)$, Asia $(\mathrm{N}=17)$, Europe $(\mathrm{N}=17)$, Oceania $(\mathrm{N}=7)$, and Antarctica $(\mathrm{N}=1)$; there are four studies without a defined region; 16 studies included islands sampling, and the remainder was carried out exclusively in mainland areas. Within America, North America had less than half of articles $(\mathrm{N}=22)$ compared to South and Central America ( $\mathrm{N}=57$, two of these in Central America), and had fewer studies than the Amazon region $(\mathrm{N}=23)$. Brazil had most of the studies $(\mathrm{N}=33)$, followed by Peru $(\mathrm{N}=19)$, Ecuador $(\mathrm{N}=9)$, the United States of America and Mexico $(\mathrm{N}=8)$, and Colombia and Canada $(\mathrm{N}=7)$. India was the country with most studies outside the Americas $(\mathrm{N}=6)$.

The fact that our review included articles in Portuguese and the largest repository of studies produced in Brazil (SciELO) might have contributed to the number of papers found in this country. On the other hand, the large number of studies in the Amazon can be explained by the existence of a group of researchers studying ferns and Melastomataceae as EIs in this region, with most of the studies in this region being published by its members. Surprisingly, more scientifically developed English-speaking countries had few studies of indicator pteridophytes inside their territories $(\mathrm{N}=19)$.

The majority of the studies $(\mathrm{N}=83$, or $62 \%$ of them) aimed to establish pteridophytes as EIs. Selection of EIs was secondary for the others, where the main goal was, for example, to analyze species distribution along an elevation gradient, to compare species distribution between two areas, or to determine the influence of abiotic variables in the distribution of species (see table 3 ).

Several taxonomic levels were used as EIs, with most studies (57\%) adopting indicator species. The remainder preferred higher levels (mainly genus or family). EIs at higher taxonomic levels may be advantageous, because they include a broader range of functional relationships, and can be more easily identified than species. Nevertheless, we should take into account the objectives and purposes of the study for choosing a species or group of species as EIs.

Within the studies that considered indicator species, $13 \%$ presented a single species; the others suggested more species. Use of a large number of indicator species seen here was also highlighted in others reviews about EIs (Jørgensen et al. 2013, Gao et al. 2015). Some studies considered an individual (the plant as a whole) as an indicator; and in 12 studies only part of a plant (such as spores, fossil or not) was considered.

Most studies (51\%) evaluated not only the indication potential of pteridophytes but also included taxa from other groups, as angiosperms (mainly monocotyledons and Melastomataceae), while five (4\%) also included animals, such as birds and insects . In all these articles, pteridophytes were studied simultaneously with other groups but without the objective of representing them, different from the seventh type of indication (next section and table 4) in which the pteridophytes reflect the richness, frequency, or abundance of other groups.

The methodologies in the studies were similar; the majority $(\mathrm{N}=92)$ used standardized sampling, although sample size varied, with presence or absence of a particular species, its abundance and/or frequency of individuals, or richness and/or diversity in the studied areas as the most important aims. 


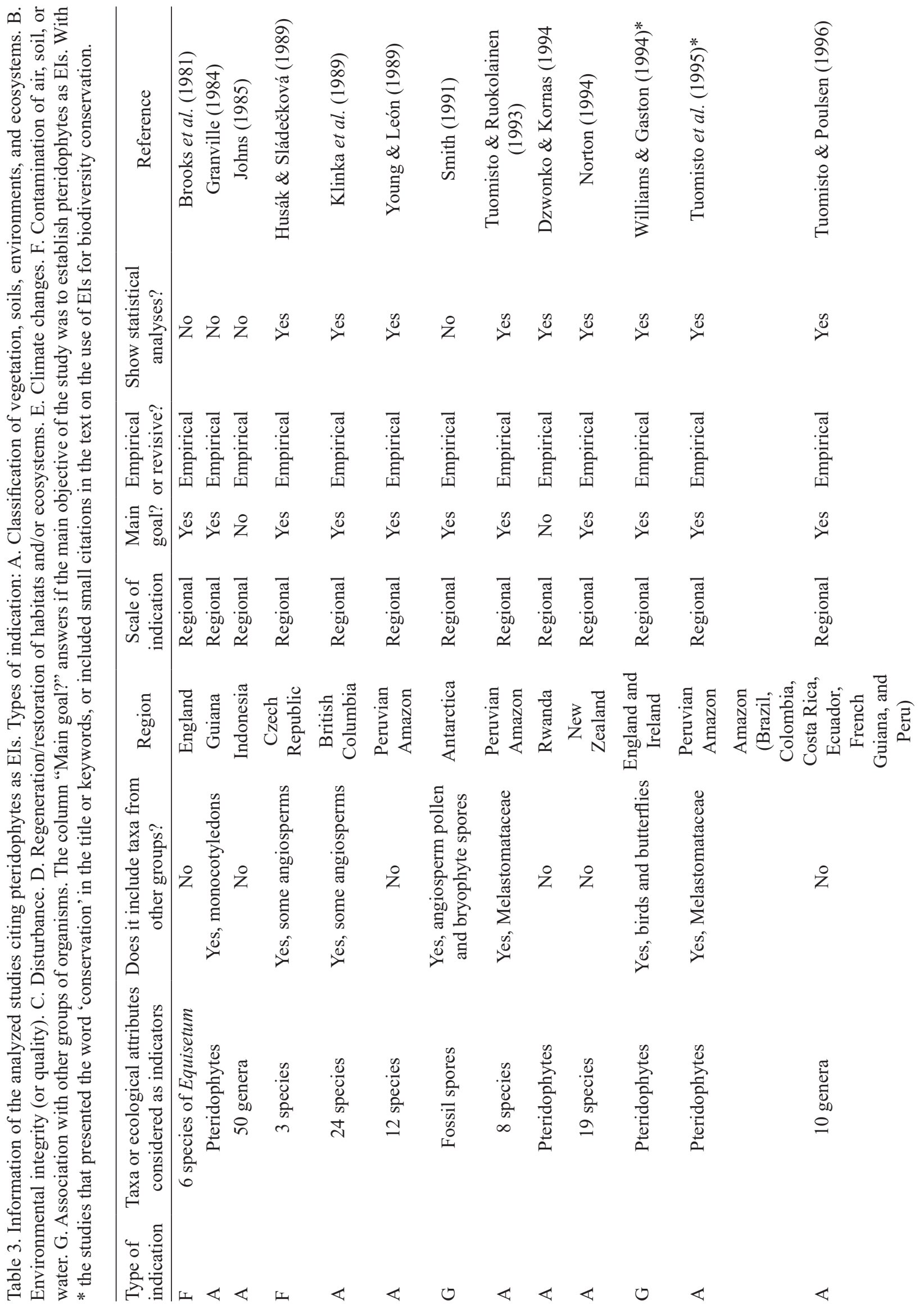




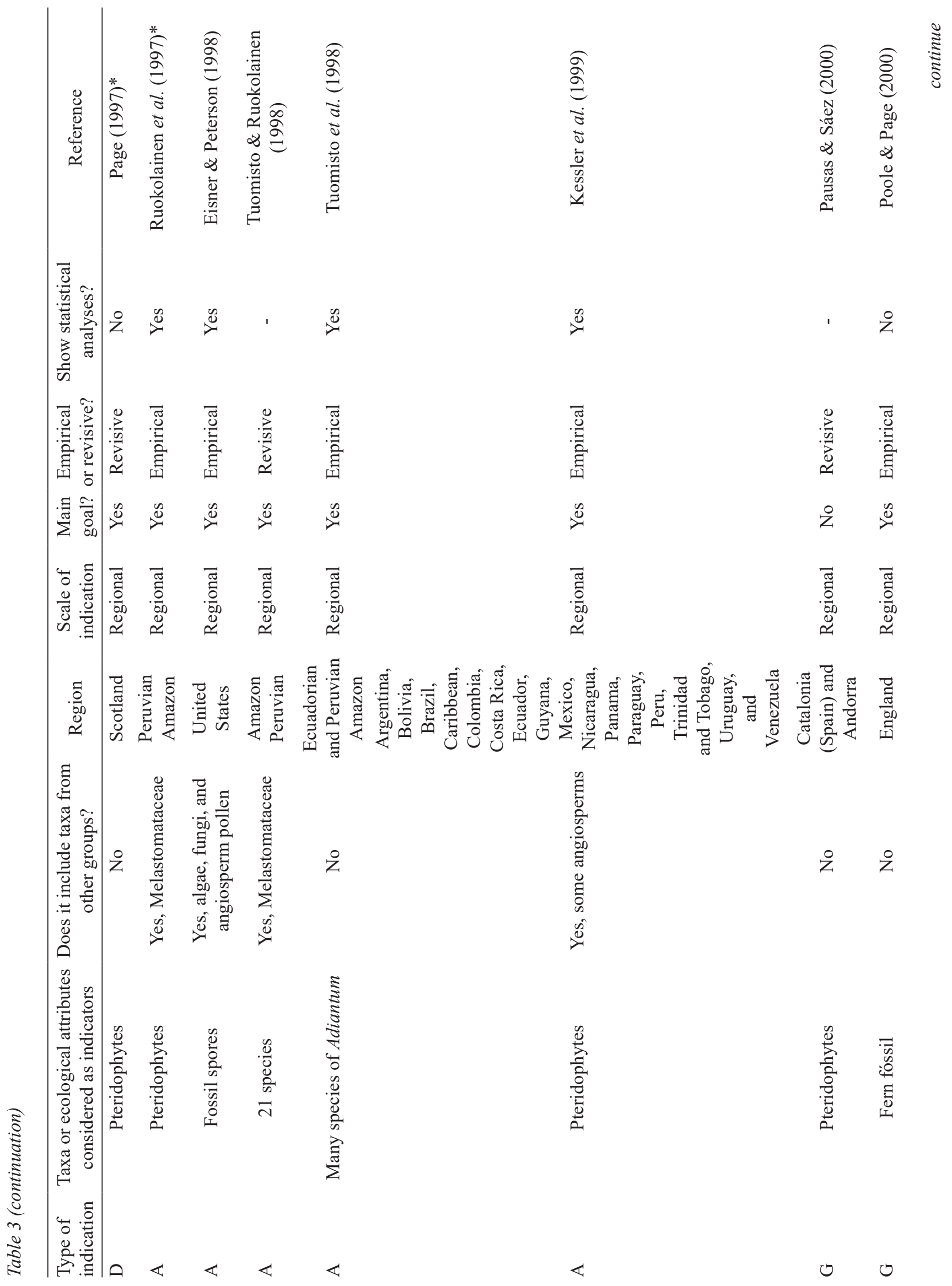




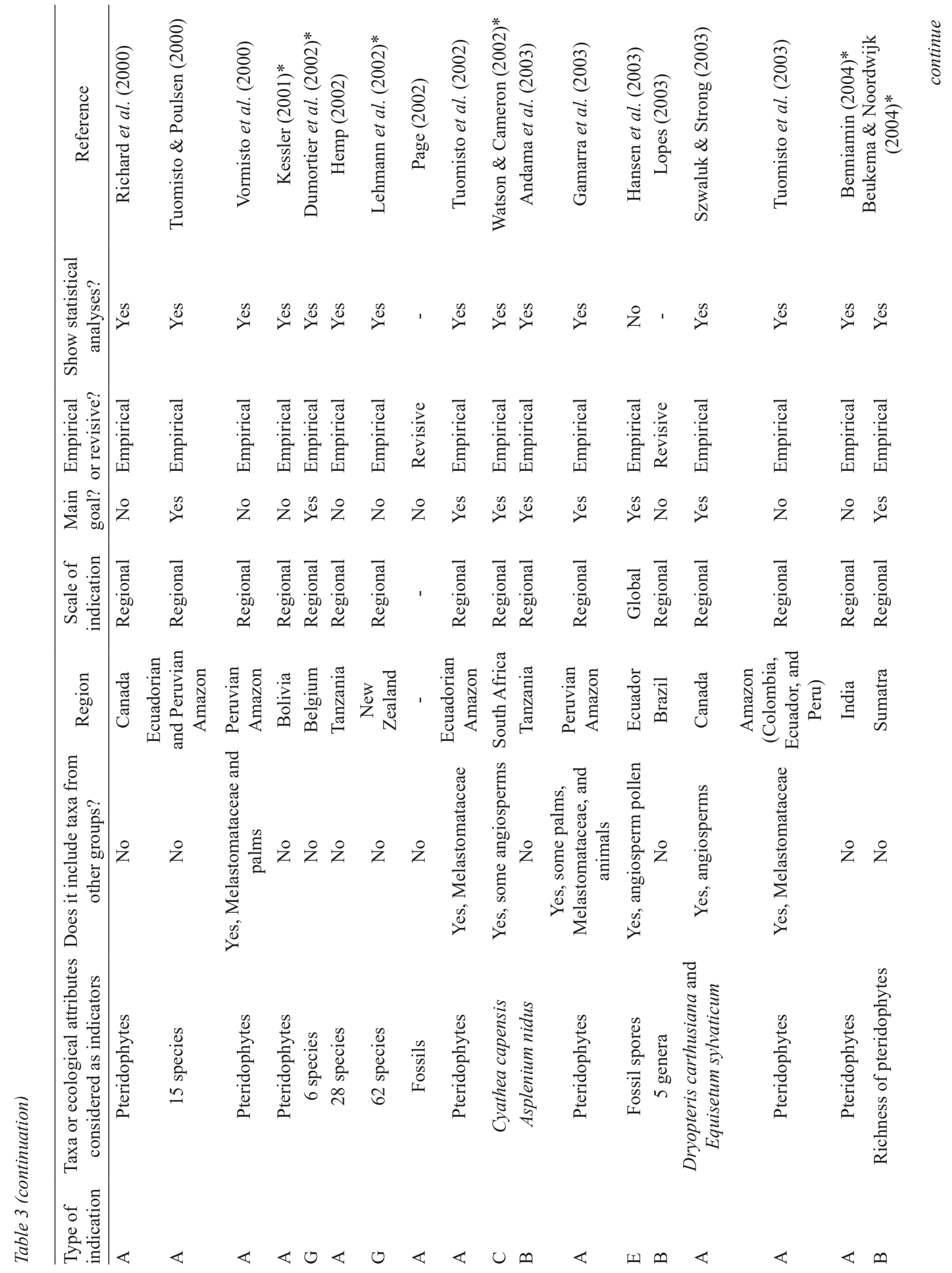




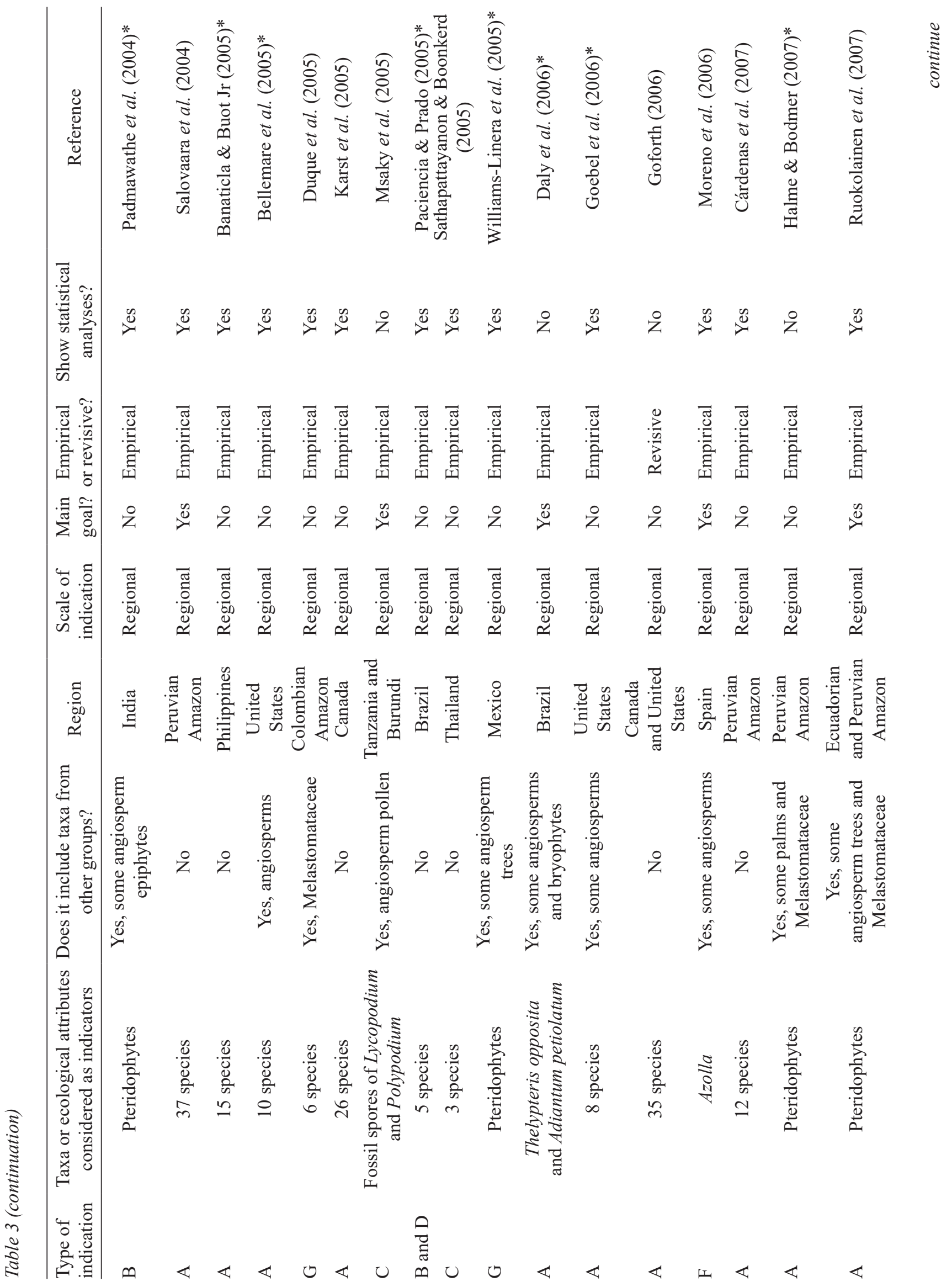




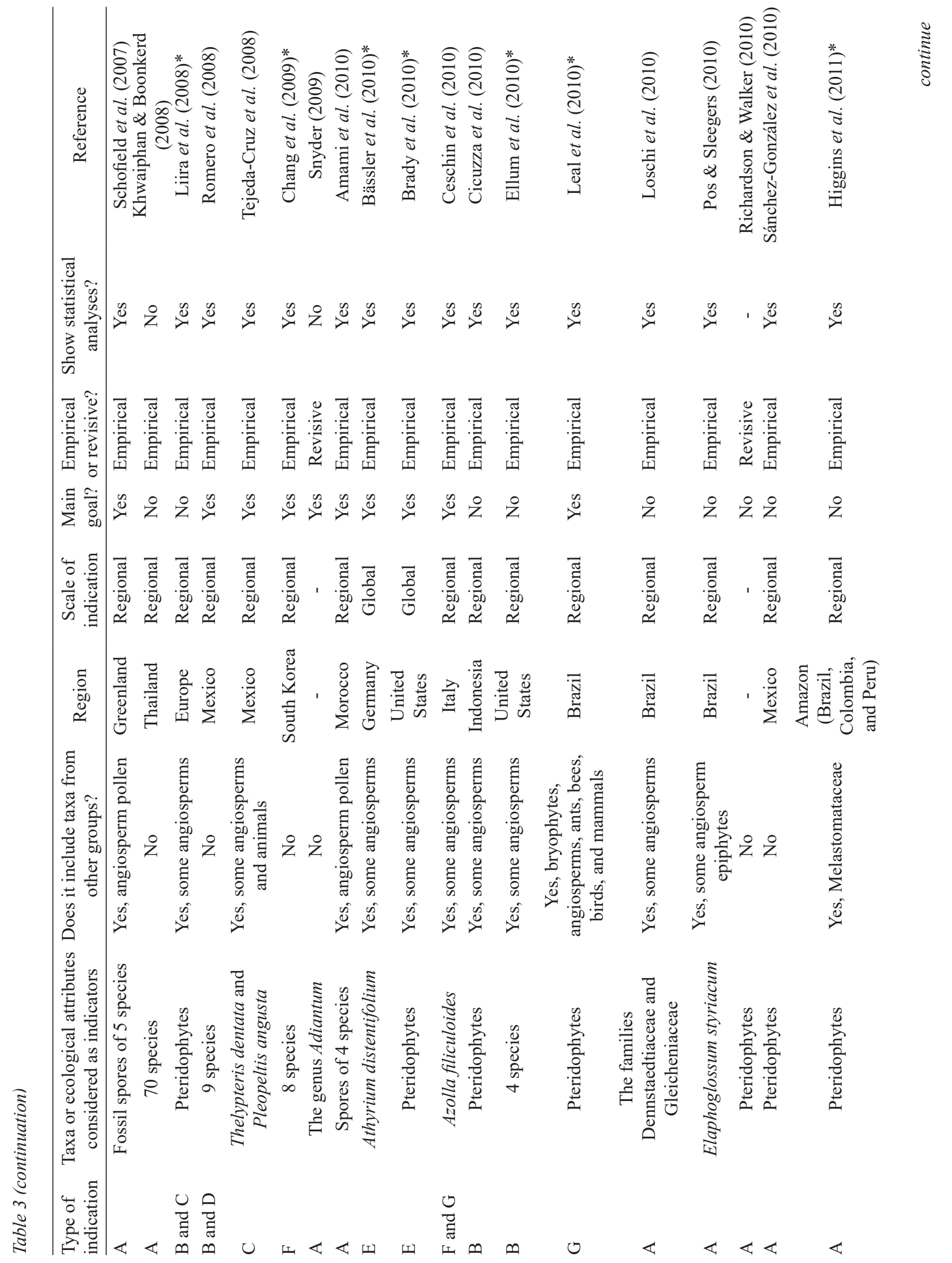




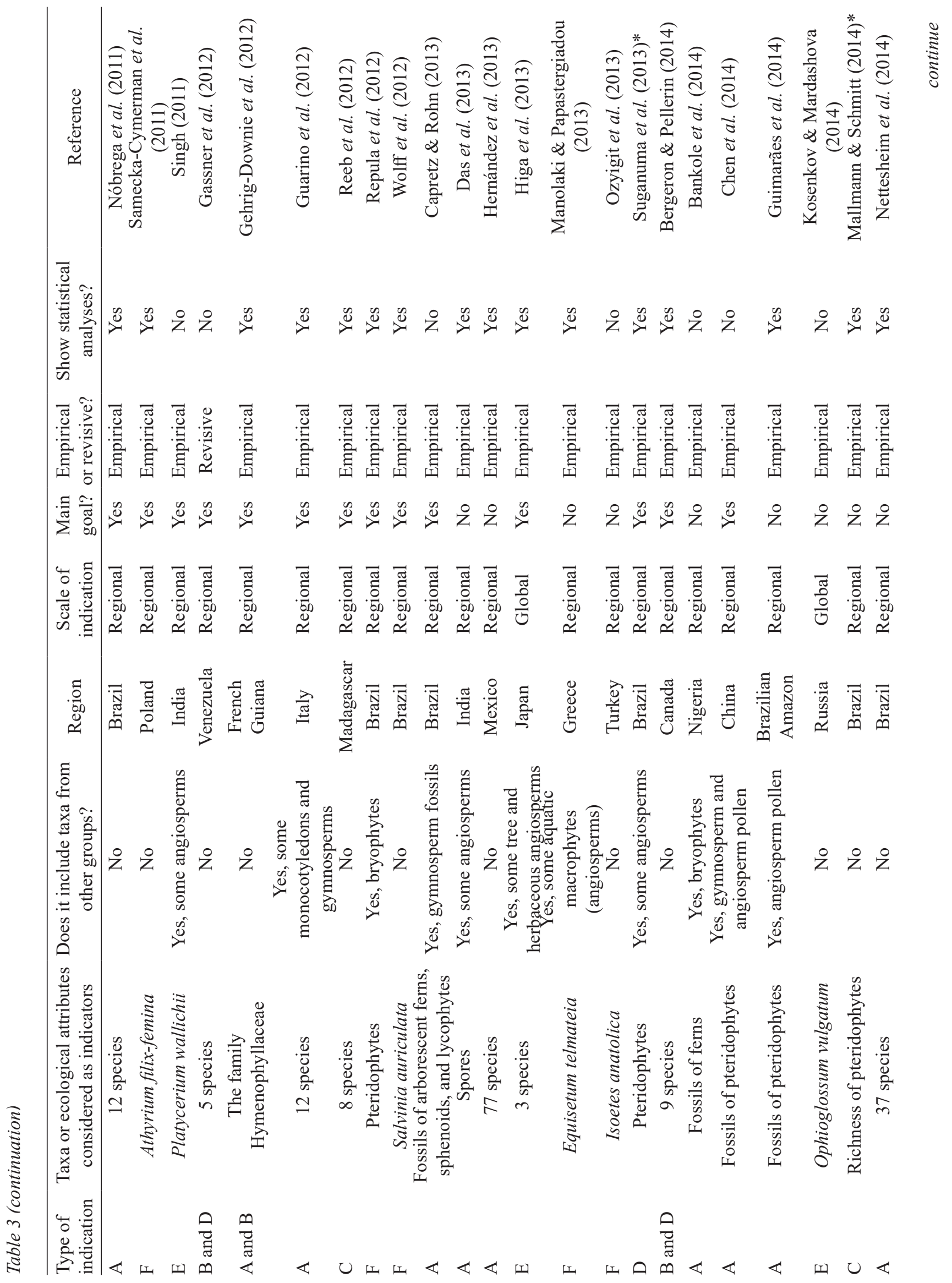




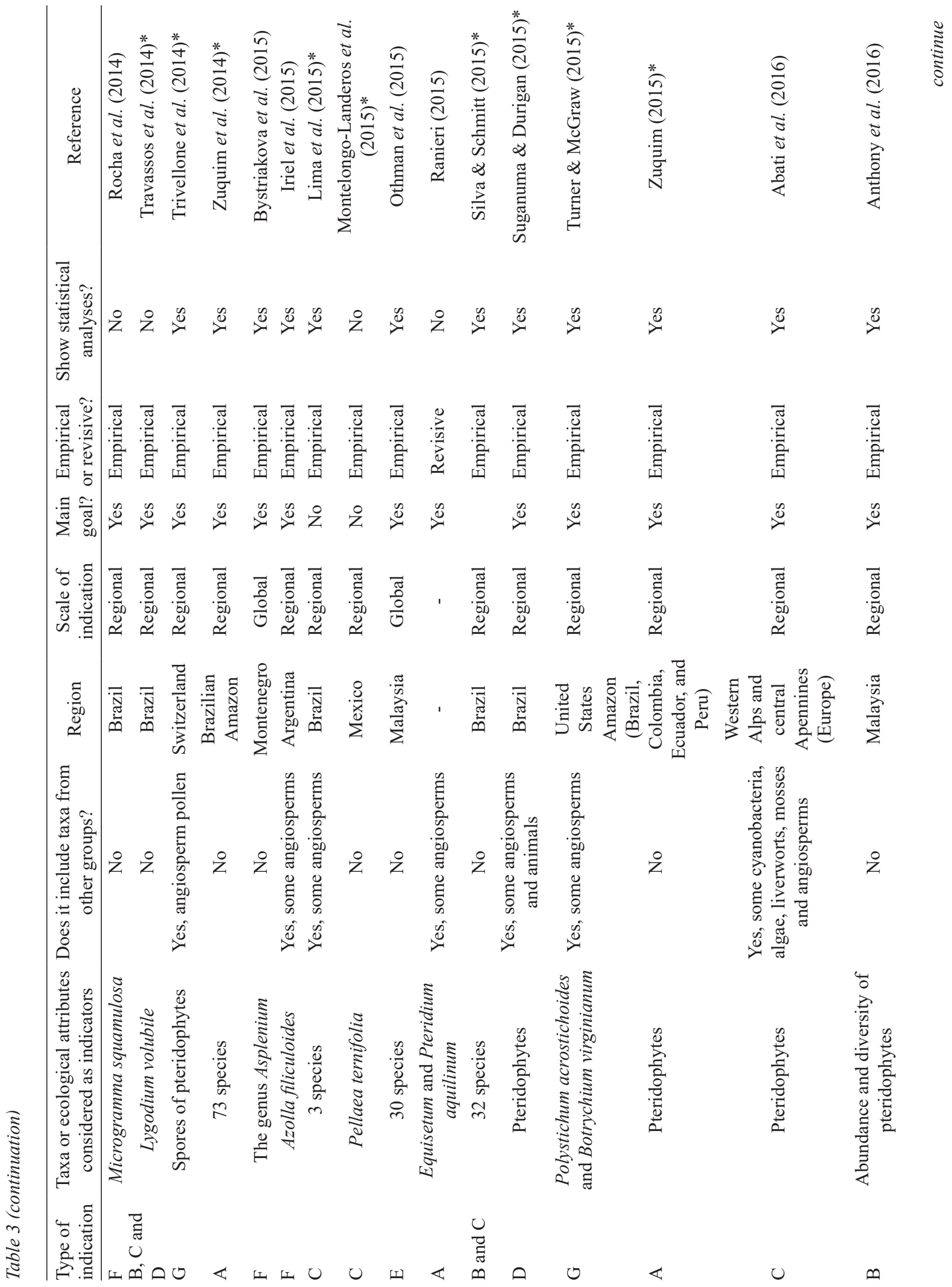




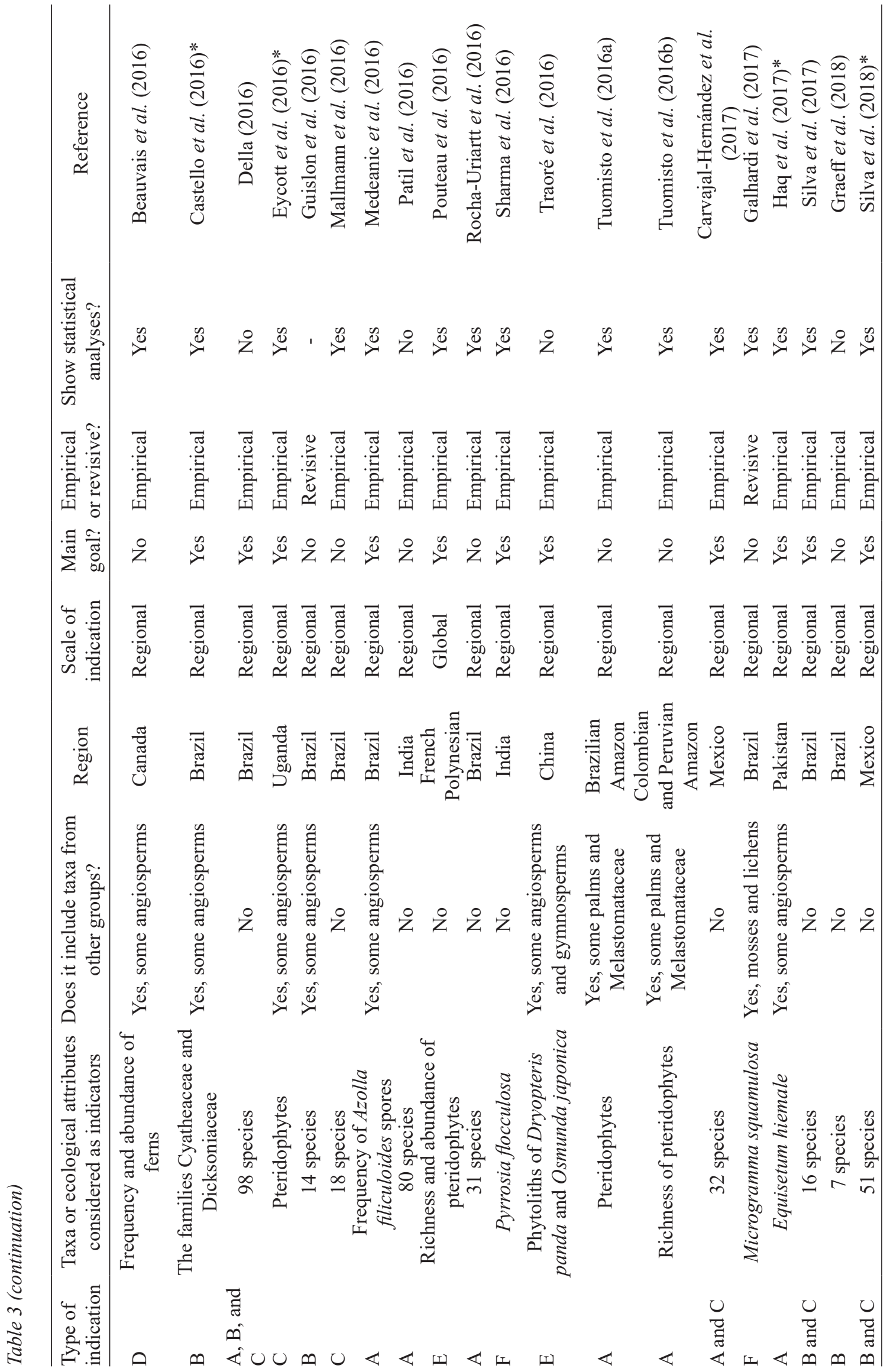




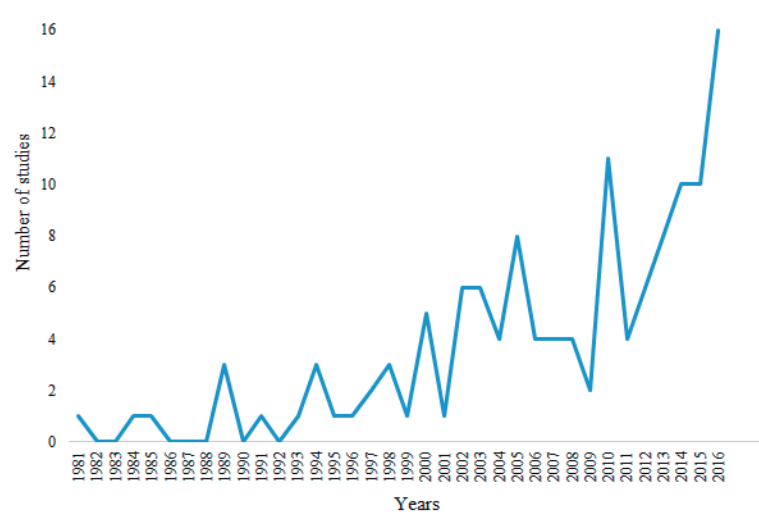

Figure 1. Temporal variation of the number of studies published with Pteridophytes as EIs from 1981 to 2016.

As expected, proposed EIs were of regional or local spatial scale. Few studies established indicators with a wider scale (global), with ten studies proposing indicators for climate changes.

About $90 \%$ of the studies were classified as empirical, and few were reviews of previous works, or in some cases presented only a logical inference without field data to support the hypothesis of the type of relationship between the indicator and indicandum. Most of the studies (78\%) presented statistical analyses using indexes (or values) of indication, richness, diversity, and/or correlation between species and abiotic variables. Those which did not present a correlation of indicandum and indicator were based only in the logic. Finally, some articles (Snyder 2009, Gassner et al. 2012) aimed at scientific dissemination only.

Surprisingly, only a few studies (as Tuomisto \& Ruokolainen 1998, Kessler \& Bach 1999) presented criteria for the selection of EIs, such as those listed in table 1. Not taking into account these criteria, time and resources might be spent studying species that will not be good EIs. Taxa that in a study are highly correlated with abiotic (or even biotic) variables, but which are hardly identified by people with low taxonomic and ecological knowledge, would have a low potential for indication. This shows the importance of using selection criteria of EIs, and we emphasize this aspect as one of the main contributions of this review.

As for the existence of an association between indicator and indicandum, we can conclude that all studies presented a logical association. For all types of objectives that the pteridophytes were studied as EIs, their relationship with the indicandum made sense. The majority of the studies $(\mathrm{N}=121)$ only hypothesized that pteridophytes would be good EIs, while only two (Goforth 2006, Halme \& Bodmer 2007) used them as EIs. Moreover, 11 studies only cited the indication potential of pteridophytes, not falling under the previous alternatives.

Types of indication - The selected studies tested the pteridophytes as EIs with different purposes (indicanda), which here we grouped into seven types (see table 4 for the references, and figure 2 for their proportions). Taking into consideration that some studies suggested more than one type of indication, the number of indications exceeds 134 (and the percentages also exceed 100\%).

a) Classification of vegetation, soils, environments, and ecosystems ( $\mathrm{N}=65$ studies, $48 \%$ of them): the presence, abundance, frequency, and diversity of pteridophytes are directly correlated with abiotic conditions, such as humidity, texture, $\mathrm{pH}$ and soil nutrients, air humidity, luminosity, precipitation, altitude, topography, and atmospheric temperature. Pteridophytes are well known to have soil preferences and adaptations that allow them to survive on different types of soils (Young \& León 1989, Tuomisto \& Ruokolainen 1993, Tuomisto \& Poulsen 2000). Different soils usually harbor different vegetation types. Thus, besides EIs be used to support the classification of soil types, they can be employed for vegetation too (when clearly defined by soil type).

b) Environmental integrity (or quality) $(\mathrm{N}=21$ studies, $16 \%$ ): evergreen forests with good canopy cover have reduced solar radiation in the understory, and tropical ones also have usually high humidity. Species adapted to the understory are, most of the time, sensitive to changes in these two conditions (Padmawathe et al. 2004, Silva et al. 2018). Therefore, such species could be considered as good initial candidates for EIs (but other criteria must also be checked at table 1). Most pteridophytes respond quickly to changes in these conditions, being much affected by canopy opening and linked alterations in environmental variables and vegetation composition (Romero et al. 2008, Bergeron \& Pellerin 2014). Usually, species richness and abundance of pteridophytes are greater in intact or well-preserved habitats. Also, species richness and abundance of pteridophytes are greater in shady forests than in more open ones or in open vegetation types because there are more shade tolerant species (umbrophiles) of pteridophytes than pioneers/ heliophiles (Tryon \& Tryon 1982, Della 2016). 
Table 4. Studies included in each type of indication.

\begin{tabular}{ll}
\hline Type of indication & References
\end{tabular}

Amami et al. (2010), Banaticla \& Buot Jr. (2005), Bankole et al. (2014), Bellemare et al. (2005),

Benniamin (2004), Capretz \& Rohn (2013), Cárdenas et al. (2007), Carvajal-Hernández et al. (2017), Chen et al. (2014), Daly et al. (2006), Das et al. (2013), Della (2016), Dzwonko \& Kornas (1994), Eisner \& Peterson (1998), Gamarra et al. (2003), Gehrig-Downie et al. (2012), Goebel et al. (2006), Goforth (2006), Granville (1984), Guarino et al. (2012), Guimarães et al. (2014), Halme

Classification of vegetation, soils, environments, and ecosystems \& Bodmer (2007), Haq et al. (2017), Hemp (2002), Hernández et al. (2013), Higgins et al. (2011), Johns (1985), Karst et al. (2005), Kessler (2001), Kessler \& Bach (1999), Khwaiphan \& Boonkerd (2008), Klinka et al. (1989), Loschi et al. (2010), Medeanic et al. (2016), Nettesheim et al. (2014),

Nóbrega et al. (2011), Norton (1994), Page (2002), Patil et al. (2016), Pos \& Sleegers (2010),

Ranieri (2015), Richard et al. (2000), Richardson \& Walker (2010), Rocha-Uriartt et al. (2016), Ruokolainen et al. (1997, 2007), Salovaara et al. (2004), Sánchez-González et al. (2010), Schofield et al. (2007), Snyder (2009), Szwaluk \& Strong (2003), Tuomisto et al. (1995, 1998, 2002, 2003, 2016a, 2016b), Tuomisto \& Poulsen (2000, 1996), Tuomisto \& Ruokolainen (1993, 1998), Vormisto et al. (2000), Young \& Léon (1989), Zuquim (2015), Zuquim et al. (2014)

Andama et al. (2003), Anthony et al. (2016), Bergeron \& Pellerin (2014), Beukema \& Van

Environmental integrity (or quality)

Noordwijk (2004), Castello et al. (2016), Cicuzza et al. (2010), Della (2016), Ellum et al. (2010), Gassner et al. (2012), Gehrig-Downie et al. (2012), Graeff et al. (2018), Guislon et al. (2016), Liira et al. (2008), Lopes (2003), Paciencia \& Prado (2005), Padmawathe et al. (2004), Romero et al.

(2008), Silva et al. (2017, 2018), Silva \& Schmitt (2015), Travassos et al. (2014)

Abati et al. (2016), Carvajal-Hernández et al. (2017), Eycott et al. (2016), Liira et al. (2008), Lima et al. (2015), Mallmann et al. (2016), Mallmann \& Schimitt (2014), Montelongo-Landeros et al.

Disturbance (2015), Msaky et al. (2005), Reeb et al. (2012), Sathapattayanon \& Boonkerd (2005), Silva et al. (2017, 2018), Silva \& Schmitt (2015), Tejeda-Cruz et al. (2008), Travassos et al. (2014), Watson \& Cameron (2002)

Regeneration/ restoration of habitats and/or ecosystems

Climate changes

Beauvais et al. (2016), Bergeron \& Pellerin (2014), Della (2016), Gassner et al. (2012), Paciencia \& Prado (2005), Page (1997), Romero et al. (2008), Suganuma et al. (2013), Suganuma \& Durigan (2015), Travassos et al. (2014)

Bässler et al. (2010), Brady et al. (2010), Bystriakova et al. (2015), Hansen et al. (2003), Higa et al. (2013), Kosenkov \& Mardashova (2014), Othman et al. (2015), Pouteau et al. (2016), Singh (2011),

Contamination of air, soil, or water

Association with other groups of organisms
Traoré et al. (2015)

Brooks et al. (1981), Ceschin et al. (2010), Chang et al. (2009), Galhardi et al. (2017), Husák \& Sládečková (1989), Iriel et al. (2015), Manolaki \& Papastergiadou (2013), Moreno et al. (2006), Ozyigit et al. (2013), Repula et al. (2012), Rocha et al. (2014), Samecka-Cymerman et al. (2011), Sharma \& Uniyal (2016), Wolff et al. (2012)

Ceschin et al. (2010), Dumortier et al. (2002), Duque et al. (2005), Leal et al. (2010), Lehmann et al. (2002), Pausas \& Sáez (2000), Poole \& Page (2000), Smith (1991), Trivellone et al. (2014), Turner \& McGraw (2015), Williams \& Gaston (1994), Williams-Linera et al. (2005) c) Disturbance ( $\mathrm{N}=17$ studies, $13 \%$ ): disturbance of a given natural area generally promotes a simplification of its community structure at first; this is usually reflected by reduction of species richness and diversity of pteridophytes and other groups (Watson \& Cameron 2002, Tejeda-Cruz et al. 2008, Reeb et al. 2012). Species that are more sensitive to changes in soil moisture and luminosity are the greatly affected; reduction of their frequency and abundance can lead to local extinction (at least temporarily). On the other hand, species that are more tolerant to sunny and dry environments might be favored in these disturbed areas, sometimes becoming dominant. Thus, disturbance can lead to many and quick changes in this group that can be easily measured and monitored.

d) Regeneration/restoration of habitats and/or ecosystems ( $\mathrm{N}=10$ studies, $7 \%$ ): as seen above, 


\section{Indication types}

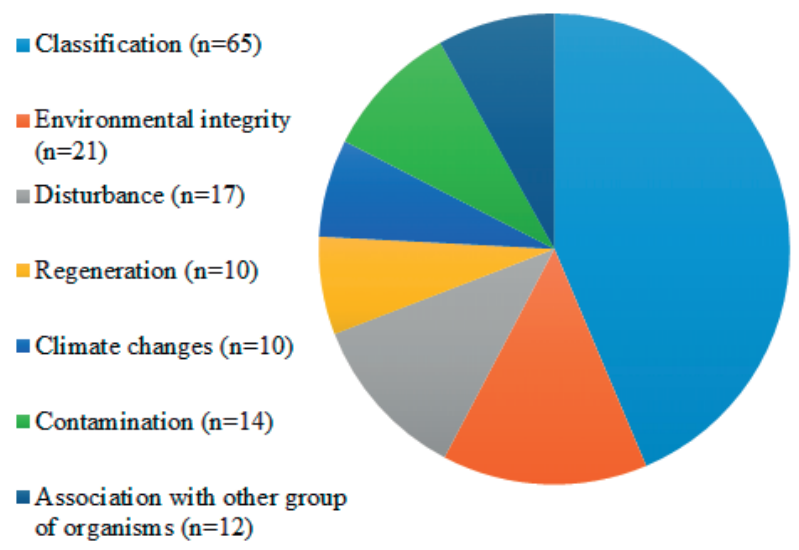

Figure 2. Proportion of each type of indication $(\mathrm{N}=149)$.

species composition and density of pteridophytes are different in disturbed areas and pristine natural environments, with primary and late secondary forests among the most important communities for these plants. Therefore, changes in the composition (or substitution) of ecological groups of pteridophytes might be used as an ecological indication.

e) Climate changes ( $\mathrm{N}=10$ studies, $7 \%$ ): observed and predicted changes in climate due to anthropogenic activities are a growing research field. It is expected that, in some regions, changes in existing climatic conditions might lead to dramatic changes in the ecosystems, including expansion or retraction of climate-sensitive pteridophytes, but also species extinction (Bässler et al. 2010, Higa et al. 2013). Sensitive species can be considered good EIs for monitoring such temporal and spatial changes.

f) Contamination of air, soil, or water ( $\mathrm{N}=14$ studies, 10\%): pteridophytes are utilized for indicating contamination or pollution caused by heavy metals (antimony, arsenic, lead, chromium, gold, etc.), in aquatic or terrestrial environments. The concentration of heavy metals in plant organs measures the degree of contamination or pollution (Repula et al. 2012, Wolff et al. 2012), and other variables would estimate the species survival capacity or degree of injuries (mainly foliar necrosis), but determine sensitive species that might not survive in these conditions. This type of indication is linked to the ability to absorb and accumulate heavy metals (in rhizomes and/or fronds) that some pteridophytes have.

g) Association with other groups of organisms ( $\mathrm{N}=12$ studies, 9\%): pteridophytes can be employed to indicate the presence of other species in a given site. It is assumed that there is a "strict relationship" or association between these species, or that some pteridophytes (e.g. tree ferns, litter basket ferns, etc) are keystone species in a certain ecosystem. Thus, a particular taxon can be used as a measure (or estimation) of diversity (such as richness, abundance, and frequency) of other associated taxon or taxa in a habitat or set of habitats.

Some studies presented more than one type of indication. Bergeron \& Pellerin (2014), Paciencia \& Prado (2005), and Romero et al. (2008) encompassed pteridophytes as EIs of the environmental integrity, as well as of regeneration/restoration of habitats. Gehrig-Downie et al. (2012) applied pteridophytes to classify vegetation and indicate environmental integrity. Carvajal-Hernández et al. (2017) suggested pteridophytes to classify vegetation, but also to indicate disturbance. Liira et al. (2008), Silva \& Schmitt (2015), Silva et al. (2017, 2018), and Travassos et al. (2014) hypothesized pteridophytes for environmental integrity, as well as for disturbance, and the last study also for regeneration/restoration. Della (2016) discussed pteridophytes to classify vegetation and to evaluate the integrity of environments and regeneration/restoration. Ceschin et al. (2010) studied pteridophytes to indicate contamination/pollution, but also to associate them with other groups of organisms.

These seven types of indication form two larger groups: one that would indicate biotic or abiotic conditions of communities/habitats (the first six types), and the other that would indicate the presence of other species in a given site (the seventh type). EIs are far more used as a tool for the first group.

Indicator taxa - Most of the taxa cited as EIs are ferns (Polypodiopsida), representatives of all subclasses (Equisetidae, Ophioglossidae, Marattiidae, and especially Polypodiidae). The families of Polypodiopsida most cited were Aspleniaceae (Asplenium), Blechnaceae (Blechnum), Cyatheaceae (Cyathea), Dennstaedtiaceae (Pteridium), Dryopteridaceae (Elaphoglossum), Equisetaceae (Equisetum), Gleicheniaceae (Dicranopteris and Sticherus), Hymenophyllaceae (Hymenophyllum and Trichomanes), Polypodiaceae (Campyloneurum and Polypodium), Pteridaceae (Adiantum and Pteris), and Thelypteridaceae (Thelypteris). Most studies adopted the traditional circumscriptions of families or genera instead of the many recent proposed changes (PPG I 2016 and references therein). 
Few lycophytes were considered as EIs, among them species of Huperzia, Isoetes, Lycopodiella, Lycopodium, and Selaginella. This difference of lycophytes and ferns cited as EIs could be due to the smaller number of species in the first group, as well as because the lycophytes are perhaps more taxonomically problematic when compared to the ferns, or even because they are sometimes considered as neglected in some context.

Although hundreds of species were studied or analyzed as EIs, only a few appeared more than once (e.g. Athyrium filix-femina, Azolla filiculoides, Equisetum hyemale, E. sylvaticum, E. telmateia, Lomagramma guianensis, Pteridium aquilinum, etc), but none was used or cited many times.

The scientific interest in developing and applying EIs - has increased substantially in the last 40 years (Niemi \& McDonald 2012 and table 3), as evidenced by the growing number of articles (Jørgensen et al. 2013, Siddig et al. 2016, and figure 1) and books (Niemi \& McDonald 2012). EIs were suggested for different objectives and purposes, as discussed in the previous sections. In spite of this, the use of EIs outside the scientific community seems restricted. The lack of broader application of these EIs may be related to slow or difficult translations of scientific information (concepts, terms, and methodologies) into the practitioners community (Jørgensen et al. 2013), or that latter does not tend to publish in scientific journals. This contributes to a knowledge gap between the public and the academics, making it difficult to measure if EIs are or not more widely utilized. However, in cases where the pteridophytes are employed as EIs by practitioners or by researchers, this use tends to be limited, given the relatively large number of purposes that exist. Thus, in addition to the possible gap between science, politics, and population, although pteridophytes are a group with lower species richness (when compared to angiosperms and insects, which are the groups most commonly employed as EIs), they are not so used as indicators. Another explanation might be their perceived 'secondary importance' in ecosystems generally dominated by angiosperms, and their usually low economic value.

The acceleration of the scientific interest in the use of EIs is partly due to the increased need to evaluate biodiversity, ecological and conservation needs in decision-making (Niemi \& McDonald 2012). Thus, EIs can be considered important tools and standards for connecting, maintaining, and improving environmental quality with policy measures (Turnhout et al. 2007).

Indeed, there has been an increase in the number of indicator taxa considered in international agreements. One example is the Montreal Process, an agreement established between 12 countries in 1994 that determines indicator species for the conservation of temperate and boreal forests (Niemi $\&$ McDonald 2012). Indicators are also being used locally as the case of the Brazilian Environment Ministry (which has the function of conserving and managing plant formations in the country and is also responsible for environmental licensing), which have some resolutions under the Brazilian Council for the Environment (CONAMA - Conselho Nacional do Meio Ambiente), as resolutions 04/1994, 261/1999, and 423/2010, which use indicator species (including pteridophytes) to characterize the successional stages of different vegetation types (see Della 2016).

However, despite the existence of indicators in these agreements and resolutions, their use to implement policies is still incipient, because of two main points. Some believe that this type of instrument oversimplifies the natural environment, leading to much uncertainty in understanding the complexity of ecosystems (although this claim is an inherent difficulty for the use of any indicator). The other is that the application of these instruments for the development of appropriate indicators for the purpose of the study, monitoring, or evaluating at hand, implies a process of selection, interaction, and aggregation of criteria and parameters that are, sometimes, not too easy to establish (Turnhout et al. 2007). In addition, transfer and translation of scientific knowledge into policy is often difficult because of common misconceptions of use of EIs, lobby (e.g. denial of anthropogenic climate changes, etc), disconnect between the progress of scientific studies and communication with those responsible for drafting laws, apart from other simpler problems as nomenclature errors or use of synonyms (Della 2016). This is somehow clear in this review that found a large number of species suggested as EIs compared to the few listed in the CONAMA resolutions (Della 2016). The use of EIs should be made more relevant (Jørgensen et al. 2013, Rapport \& Hildén 2013) to connect the science-policy interface (Turnhout et al. 2007).

EIs are not only having low use to help support policies, but they also have a limited use in some fields of Nature research as conservation biology. For the 
pteridophytes, all seven types of indication considered here could be directly or indirectly applied in this field, especially those dealing with integrity (or quality) of environments, disturbance, regeneration/restoration of habitats and/or ecosystems, climate changes, and contamination (pollution). Those studies with $*$ in table $3(\mathrm{~N}=38$, or $28 \%)$ had the word 'conservation' in the title or keywords, or included use of EIs for biodiversity conservation. Nevertheless, this aspect tended to be treated somehow superficially and might have been included to try to reach a larger audience, and not because it was part of the main study objectives.

Directions for future research - An important step in the selection of EIs is the establishment of criteria since the application of them minimizes the chance of carrying out studies with species and/or group of species that are not suitable indicators (McGeoch 1998, Heink \& Kowarik 2010b), thus saving time and resources. However, as seen here, few studies have established criteria, and most of these studies did not discuss sufficiently such criteria. Therefore, there is a need to research into creation and use of criteria for EIs, as these indicators are becoming important tools in the context of worldwide decreasing resources for scientific research combined with stricter environment resolutions for carrying out development projects.

$13 \%$ of the studies adopted single species as EI, instead of a group of species or other taxonomic or functional groups. However, use of more than one species with similar traits may provide better resolution of the indicandum and would be more likely to be applicable on a larger scale. Use of groups of a broader range of taxonomic and functional entities would cover a larger habitat diversity, as well as, more types of environmental responses (McGeoch 1998). Thus, whenever possible, use of groups of similar species (little adopted in the studies selected here dealing with several or many species) may be a more advisable procedure than an isolated species as EI. However, selection of criteria must also be clearly spelled out in this case.

This overview also shows other priorities for the use of pteridophytes as EIs. There is a need for more studies to check broader deficiencies of some selected EIs, and to verify if the proposed use is the only or if the EI could be applied for another type (s) of indication. Related, it is also important to evaluate the use of these EIs outside research studies (e.g. impact assessment, monitoring, etc), to understand and reduce the difficulties in this use, and how to increase their adoption in technical policy documents.

\section{Conclusions}

Use of pteridophytes as EIs is becoming more conventional, but studies are having many different objectives, leading to a wide variety of indication types. In one hand, this shows a great potential of this group as EIs, which is also supported by many studies employing similar methodologies, leading to a large number of species, genera, and families to be suggested as EIs. However, there is a lack of studies demonstrating their practical application and which criteria were adopted to choose the/these EIs.

\section{Acknowledgements}

We are grateful to Regina Hirai, Maria Leonor D’El Rei Souza, Tania Tarabini Castellani, and Pedro Fiaschi, for comments on previous versions of the study, and to Associate Editor, Claudia Baider, and the anonymous reviewers, for corrections and suggestions on this article.

\section{Literature cited}

Abati, S., Minciardi, M.R., Ciadamidaro, S., Fattorini, S. \& Ceschin, S. 2016. Response of macrophyte communities to flow regulation in mountain streams. Environmental Monitoring and Assessment 188: 1-12.

Alfsen, K.H. \& Sæbø, H.V. 1993. Environmental quality indicators: background, principles and examples from Norway. Environmental and Resource Economics 3: 415-435.

Amami, B., Muller, S.D., Rhazi, L., Grillas, P., Rhazi, M. \& Bouahim, S. 2010. Modern pollen-vegetation relationships within a small mediterranean temporary pool (western Morocco). Review of Palaeobotany and Palynology 162: 213-225.

Andama, E.E., Michira, M.C. \& Luilo, G.B. 2003. Studies on epiphytic ferns as potential indicators of forest disturbances. Paper submitted to the XII World Forest Congress, Québec City, Canada. Available at http:// www.fao.org/docrep/ARTICLE/WFC/XII/0129-B1. HTM (access in 23-V-2017).

Anthony, F., Majuakim, L. \& Suleiman, M. 2016. Fern diversity in primary and secondary forests of Danum Valley and Ulu Segama forest complex, Lahad Datu, Sabah. Transactions on Science and Technology 3: 77-84. 
Banaticla, M.C.N. \& Buot Jr., I.E. 2005. Altitudinal zonation of pteridophytes on Mt. Banahaw de Lucban, Luzon Island, Philippines. Plant Ecology 180: 135-151.

Bankole, S.I., Schrank, E. \& Osterloff, P.L. 2014. Palynostratigraphy, palaeoclimates and palaeodepositional environments of the Miocene aged Agbada Formation in the Niger Delta, Nigeria. Journal of African Earth Sciences 95: 41-62.

Bässler, C., Müller, J., Hothorn, T., Kneib, T., Badeck, F. \& Dziock, F. 2010. Estimation of the extinction risk for high-montane species as a consequence of global warming and assessment of their suitability as crosstaxon indicators. Ecological Indicators 10: 341-352.

Beauvais, M.P., Pellerin, S. \& Lavoie, C. 2016. Beta diversity declines while native plant species richness triples over 35 years in a suburban protected area. Biological Conservation 195: 73-81.

Bellemare, J., Motzkin, G. \& Foster, D.R. 2005. Rich mesic forests: Edaphic and physiographic drivers of community variation in western Massachusetts. Rhodora 107: 239-283.

Benniamin, A. 2004. Fern diversity of Western Ghats of India. Manonmaniam Sundaranar University.

Bergeron, A. \& Pellerin, S. 2014. Pteridophytes as indicators of urban forest integrity. Ecological Indicators 38: 40-49.

Beukema, H. \& Van Noordwijk, M. 2004. Terrestrial pteridophytes as indicators of a forest-like environment in rubber production systems in the lowlands of Jambi, Sumatra. Agriculture, Ecosystems and Environment 104: 63-73.

Brady, T.J., Monleon, V.J. \& Gray, A.N. 2010. Calibrating vascular plant abundance for detecting future climate changes in Oregon and Washington, USA. Ecological Indicators 10: 657-667.

Brooks, R.R., Holzbecher, J. \& Ryan, D.E. 1981. Horsetails (Equisetum) as indirect indicators of gold mineralization. Journal of Geochemical Exploration 16: 21-26.

Bystriakova, N., Peregrym, M. \& Dragicevic, S. 2015. Effect of environment on distributions of rock ferns in the Mediterranean climate: The case of the genus Asplenium in Montenegro. Flora 215: 84-91.

Capretz, R.L. \& Rohn, R. 2013. Lower Permian stems as fluvial paleocurrent indicators of the Parnaíba Basin, northern Brazil. Journal of South American Earth Sciences 45: 69-82.

Cárdenas, G.G., Halme, K.J. \& Tuomisto, H. 2007. Riqueza y distribución ecológica de especies de pteridofitas en la zona del río Yavarí-Mirím, Amazonia Peruana. Biotropica 39: 637-646.

Carvajal-Hernández, C.I., Krömer, T., López-Acosta, J.C., Gómez-Díaz, J.A. \& Kessler, M. 2017. Conservation value of disturbed and secondary forests for ferns and lycophytes along an elevational gradient in Mexico. Applied Vegetation Science 20: 662-672.
Castello, A.C.D., Coelho, S. \& Cardoso-Leite, E. 2016. Lianas, tree ferns and understory species: indicators of conservation status in the Brazilian Atlantic rainforest remnants, southeastern Brazil. Brazilian Journal of Biology 77: 213-226.

Ceschin, S., Zuccarello, V. \& Caneva, G. 2010. Role of macrophyte communities as bioindicators of water quality: Application on the Tiber river basin (Italy). Plant Biosystems 144: 528-536.

Chang, J.S., Yoon, I.H. \& Kim, K.W. 2009. Heavy metal and arsenic accumulating fern species as potential ecological indicators in As-contaminated abandoned mines. Ecological Indicators 9: 1275-1279.

Chen, B., Zheng, Z., Huang, K., Zheng, Y., Zhang, G., Zhang, Q. \& Huang, X. 2014. Radionuclide dating of recent sediment and the validation of pollenenvironment reconstruction in a small watershed reservoir in southeastern China. Catena 115: 29-38.

Cicuzza, D., Kessler, M., Pitopang, R., Sri, S. \& Gradstein, S.R. 2010. Terrestrial herb communities of tropical submontane and tropical montane forests in Central Sulawesi, Indonesia. In: T. Tscharntke, C. Leuschner, E. Veldkamp, H. Faust, E. Guhardja \& A. Bidin (eds.). Tropical Rainforests and Agroforests under Global Change, Springer-Verlag, Berlin. pp. 377-390.

Dale, V.H. \& Beyeler, S.C. 2001. Challenges in the development and use of ecological indicators. Ecological Indicators 1: 3-10.

Daly, D.C., Costa, D.P. \& Melo, A.W.F. 2006. The "salão" vegetation of Southwestern Amazonia. Biodiversity and Conservation 15: 2905-2923.

Das, S., Ghosh, R. \& Bera, S. 2013. Application of nongrass phytoliths in reconstructing deltaic environments: A study from the Indian Sunderbans. Palaeogeography, Palaeoclimatology, Palaeoecology 376: 48-65.

Della, A.P. 2016. Pteridófitas como indicadores ecológicos: revisão geral e aplicações em Santa Catarina. Trabalho de Conclusão de Curso, Universidade Federal de Santa Catarina, Florianópolis.

Dufrêne, M. \& Legendre, P. 1997. Species assemblages and indicator species: The need for a flexible asymmetrical appoach. Ecological Monographs 67: 345-366.

Dumortier, M., Butaye, J., Jacquemyn, H., Van Camp, N., Lust, N. \& Hermy, M. 2002. Predicting vascular plant species richness of fragmented forests in agricultural landscapes in central Belgium. Forest Ecology and Management 158: 85-102.

Duque, A.J., Duivenvoorden, J.F., Cavelier, J., Sánchez, M., Polanía, C. \& León, A. 2005. Ferns and Melastomataceae as indicators of vascular plant composition in rain forests of Colombian Amazonia. Plant Ecology 178: 1-13. 
Dzwonko, Z. \& Kornas, J. 1994. Patterns of species richness and distribution of pteridophytes in Rwanda (Central Africa): a numerical approach. Journal of Biogeography 21: 491-501.

Eisner, W.R. \& Peterson, K.M. 1998. Pollen, fungi and algae as age indicators of drained lake basins near Barrow, Alaska. The 7th International Permafrost Conference 55: 245-250.

Ellum, D.S., Ashton, M.S. \& Siccama, T.G. 2010. Spatial pattern in herb diversity and abundance of second growth mixed deciduous-evergreen forest of southern New England, USA. Forest Ecology and Management 259: 1416-1426.

Eycott, A.E., Esaete, J., Reinio, J., Telford, R.J. \& Vandvik, V. 2016. Plant functional group responses in an African tropical forest recovering from disturbance. Plant Ecology \& Diversity 9: 69-80.

Galhardi, J.A., García-Tenorio, R., Díaz Francés, I., Bonotto, D.M. \& Marcelli, M.P. 2017. Natural radionuclides in lichens, mosses and ferns in a thermal power plant and in an adjacent coal mine area in southern Brazil. Journal of Environmental Radioactivity 167: 43-53.

Gamarra, G.G.R., De La Cruz, A.A., Martínez, N.L., Ríos, S.T., Gonzáles, C.R., Salazar, E.Z., Vargas, V.H.P., Soini, P., Ruokolainen, K. J. J. \& Cárdenas, R. 2003. Comparaciones florísticas y faunísticas entre diferentes lugares de bosques de tierra firme en la selva baja de la Amazonía Peruana. Folia Amazónica 14: 35-72.

Gao, T., Nielsen, A.B. \& Hedblom, M. 2015. Reviewing the strength of evidence of biodiversity indicators for forest ecosystems in Europe. Ecological Indicators 57: 420-434.

Gassner, P., Mostacero, J. \& Weiss, M. 2012. Establishing suitable bio-indicators for cloud forest management. Available at http://www.biodiversityscience. com/2012/09/26/bioindicators-cloud-forestmanagement/ (access in 23-V-2017).

Gehrig-Downie, C., Marquardt, J., Obregón, A., Bendix, J. \& Gradstein, S.R. 2012. Diversity and vertical distribution of filmy ferns as a tool for identifying the novel forest type "tropical lowland cloud forest". Ecotropica 18: 35-44.

Goebel, P.C., Pregitzer, K.S. \& Palik, B.J. 2006. Landscape hierarchies influence riparian ground-flora communities in Wisconsin, USA. Forest Ecology and Management 230: 43-54.

Goforth, T. 2006. Crow dog native ferns and gardens. Available at http://www.crowdognativeferns.com/ (access in 23-V-2017).

Graeff, V., Mottin, I.G., Rocha-Uriartt, L., Osório, D.M.M. \& Schmitt, J.L. 2018. Assessment of a subtropical riparian forest focusing on botanical, meteorological, ecological characterization and chemical analysis of rainwater. Revista Ambiente \& Água 13: e2140.
Granville, J.J. 1984. Monocotyledons and pteridophytes indicators of environmental constraints in the tropical vegetation. Candollea 39: 265-269.

Guarino, R., Domina, G. \& Pignatti, S. 2012. Ellenberg's indicator values for the flora of Italy - first update: Pteridophyta, Gymnospermae and Monocotyledoneae. Flora Mediterranea 22: 197-209.

Guimarães, J.T.F., Souza-Filho, P.W.M., Alves, R., de Souza, E.B., da Costa, F.R., Reis, L.S., Sahoo, P.K., Manes, C.L.O., Silva Júnior, R.O., Oti, D. \& Dall'Agnol, R. 2014. Source and distribution of pollen and spores in surface sediments of a plateau lake in southeastern Amazonia. Quaternary International 352: 181-196.

Guislon, A. V., Ceron, K., Elias, G.A., Santos, R. \& Citadini-Zanette, V. 2016. Estrutura da vegetação herbácea em paisagens ciliares no sul de Santa Catarina. Revista Ambiente e Água 11: 650-664.

Halme, K.J. \& Bodmer, R.E. 2007. Correspondence between scientific and traditional ecological knowledge: Rain forest classification by the non-indigenous riberenos in Peruvian Amazonia. Biodiversity and Conservation 16: 1785-1801.

Hansen, B.C.S., Rodbell, D.T., Seltzer, G.O., León, B., Young, K.R. \& Abbott, M. 2003. Late-glacial and Holocene vegetational history from two sites in the western Cordillera of southwestern Ecuador. Palaeogeography, Palaeoclimatology, Palaeoecology 194: 79-108.

Haq, F., Ahmad, H., Iqbal, Z., Alam, M. \& Aksoy, A. 2017. Multivariate approach to the classification and ordination of the forest ecosystem of Nandiar valley western Himalayas. Ecological Indicators 80: 232-241.

Heink, U. \& Kowarik, I. 2010a. What are indicators? On the definition of indicators in ecology and environmental planning. Ecological Indicators 10: 584-593.

Heink, U. \& Kowarik, I. 2010b. What criteria should be used to select biodiversity indicators? Biodiversity and Conservation 19: 3769-3797.

Hemp, A. 2002. Ecology of the pteridophytes on the southern slopes of Mt. Kilimanjaro. I. Altitudinal distribution. Plant Ecology 159: 211-239.

Hernández, A.L.C., Sánchez-González, A. \& TejeroDíez, J. 2013. Pteridophytes of a semiarid natural protected area in Central Mexico. Natural Areas Journal 33: 177-188.

Higa, M., Nakao, K., Tsuyama, I., Nakazono, E., Yasuda, M., Matsui, T. \& Tanaka, N. 2013. Indicator plant species selection for monitoring the impact of climate change based on prediction uncertainty. Ecological Indicators 29: 307-315.

Higgins, M.A., Ruokolainen, K., Tuomisto, H., Llerena, N., Cardenas, G., Phillips, O.L., Vásquez, R. \& Räsänen, M. 2011. Geological control of floristic composition in Amazonian forests. Journal of Biogeography 38: 2136-2149. 
Husák, S. V. \& Sládečková, A. 1989. Freshwater macrophytes as indicators of organic pollution. Acta Hydrochimica et Hydrobiologica 17: 693-697.

Iriel, A., Dundas, G., Cirelli, A.F. \& Lagorio, M.G. 2015. Effect of arsenic on reflectance spectra and chlorophyll fluorescence of aquatic plants. Chemosphere 119: 697-703.

Johns, R.J. 1985. Altitudinal zonation of pteridophytes in Papuasia. Proceedings of the Royal Society of Edinburgh, Section B, Biological Sciences 86: 381-389.

Jørgensen, S.E., Burkhard, B. \& Müller, F. 2013. Twenty volumes of Ecological Indicators - An accounting short review. Ecological Indicators 28: 4-9.

Karst, J., Gilbert, B. \& Lechowicz, M.J. 2005. Fern community assembly: The roles of chance and the environment at local and intermediate scales. Ecology 86: 2473-2486.

Kessler, M. 2001. Pteridophyte species richness in andean forests in Bolivia. Biodiversity and Conservation 10: 1473-1495.

Kessler, M. \& Bach, K. 1999. Using indicator families for vegetation classification in species-rich Neotropical forests. Phytocoenologia 29: 485-502.

Khwaiphan, W. \& Boonkerd, T. 2008. The pteridophyte flora of Khao Khiao, Khao Yai National Park, Thailand. Natural History Journal of Chulalongkorn University 8: 69-82.

Klinka, K., Krajina, V.J., Ceska, A. \& Scagel, A.M. 1989. Indicator plants of coastal British Columbia. UBC Press, Vancouver, pp. 287.

Kosenkov, A. \& Mardashova, M. 2014. Distribution of adder's tongue (Ophioglossum vulgatum L.) in the vicinity of the White Sea Biological Station of Moscow State University (Kandalaksha Gulf). 1st Student Workshop on Ecology and Optics of the White Sea. pp. 37-42.

Leal, I.R., Bieber, A.G.D., Tabarelli, M. \& Andersen, A.N. 2010. Biodiversity surrogacy: Indicator taxa as predictors of total species richness in Brazilian Atlantic forest and Caatinga. Biodiversity and Conservation 19: 3347-3360.

Lehmann, A., Leathwick, J.R. \& Overton, J.M.C. 2002. Assessing New Zealand fern diversity from spatial predictions of species assemblages. Biodiversity and Conservation 11: 2217-2238.

Liira, J., Schmidt, T., Aavik, T., Arens, P., Augenstein, I., Bailey, D., Billeter, R., Bukáček, R., Burel, F., De Blust, G., De Cock, R., Dirksen, J., Edwards, P.J., Hamerský, R., Herzog, F., Klotz, S., Kühn, I., Le Coeur, D., Miklová, P., Roubalova, M., Schweiger, O., Smulders, M.J.M., van Wingerden, W.K.R.E., Bugter, R. \& Zobel, M. 2008. Plant functional group composition and large-scale species richness in European agricultural landscapes. Journal of Vegetation Science 19: 3-14.
Lima, P.B., Lima, L.F., Santos, B.A., Tabarelli, M. \& Zickel, C.S. 2015. Altered herb assemblages in fragments of the Brazilian Atlantic forest. Biological Conservation 191: 588-595.

Lopes, M.S. 2003. Florística, aspectos ecológicos e distribuição altitudinal das pteridófitas em remanescente de floresta atlântica no estado de Pernambuco, Brasil. Dissertação de Mestrado, Universidade Federal de Pernambuco, Recife.

Loschi, R.A., Aldo, J., Pereira, A., Luiz, E. \& Machado, M. 2010. Variações florísticas e estruturais de uma voçoroca em Itumirim, Minas Gerais. Cerne 16: 479-498.

Mallmann, I.T. \& Schmitt, J.L. 2014. Riqueza e composição florística da comunidade de samambaias na mata ciliar do rio Cadeia, Rio Grande do Sul, Brasil. Ciência Florestal 24: 97-109.

Mallmann, I.T., Silva, V.L. \& Schmitt, J.L. 2016. Estrutura comunitária de samambaias em mata ciliar: avaliação em gradiente de antropização. Revista Ambiente e Água 11: 110-124.

Manolaki, P. \& Papastergiadou, E. 2013. The impact of environmental factors on the distribution pattern of aquatic macrophytes in a middle-sized Mediterranean stream. Aquatic Botany 104: 34-46.

McGeoch, M. 1998. The selection, testing and application of terrestrial insects as bioindicators. Biological Reviews 73: 181-201.

Medeanic, S., Costa, C.S.B. \& Diniz, D. 2016. Modern pollen-vegetation relationships in saltmarsh habitats along a salinity gradient of a fluvial estuary. Review of Palaeobotany and Palynology 233: 67-76.

Montelongo-Landeros, M., Alba-Avila, J.A., RomeroMéndez, U. \& García-De la Peña, C. 2015. Pteridofitas de las sierras El Sarnoso y Mapimí en Durango, México. Revista Mexicana de Biodiversidad 86: 448-456.

Moran, R.C. 2008. Neotropical genera of ferns and lycophytes: a guide for students. New York Botanical Garden, New York.

Moreno, J.L., Navarro, C. \& Heras, J. 2006. Propuesta de un índice de vegetación acuática (IVAM) para la evaluación del estado trófico de los ríos de CastillaLa Mancha: comparación con otros índices bióticos. Limnetica 25: 821-838.

Msaky, E.S., Livingstone, D. \& Davis, O.K. 2005. Paleolimnological investigations of anthropogenic environmental change in Lake Tanganyika: V. Palynological evidence for deforestation and increased erosion. Journal of Paleolimnology 34: 73-83.

Nettesheim, F.C., Damasceno, E.R. \& Sylvestre, L.S. 2014. Different slopes of a mountain can determine the structure of ferns and lycophytes communities in a tropical forest of Brazil. Anais da Academia Brasileira de Ciências 86: 199-210.

Niemi, G.J. \& McDonald, M.E. 2012. Application of ecological indicators. Annual Review of Ecology, Evolution, and Systematics 35: 89-111. 
Nóbrega, G.A., Eisenlohr, P. V., Paciencia, M.L.B., Prado, J. \& Aidar, M.P.M. 2011. A composição florística e a diversidade de pteridófitas diferem entre a floresta de restinga e a floresta ombrófila densa das terras baixas do Núcleo Picinguaba/PESM, Ubatuba/ SP? Biota Neotropica 11: 153-164.

Norton, D. 1994. Relationships between pteridophytes and topography in a lowland south westland podocarp forest. New Zealand Journal of Botany 32: 401-408.

Öster, M., Persson, K. \& Eriksson, O. 2008. Validation of plant diversity indicators in semi-natural grasslands. Agriculture, Ecosystems and Environment 125: 65-72.

Othman, R., Mohd Latiff, N.H., Tukiman, I. \& Hashim, K.S.H.Y. 2015. Effects of altitude and microclimate on the distribution ferns in and urban areas. Jurnal Teknologi 77: 125-131.

Ozyigit, I.I., Dogan, I., Eskin, B., Keskin, M., Demir, G. \& Yalcin, I.E. 2013. Mineral element uptake status of endemic Isoetes anatolica Prada \& Rolleri populations from Bolu-Turkey. Pakistan Journal of Botany 45: 515-519.

Paciencia, M.L.B. \& Prado, J. 2005. Distribuição espacial da assembléia de pteridófitas em uma paisagem fragmentada de Mata Atlântica no sul da Bahia, Brasil. Hoehnea 32: 103-117.

Padmawathe, R., Qureshi, Q. \& Rawat, G.S. 2004. Effects of selective logging on vascular epiphyte diversity in a moist lowland forest of Eastern Himalaya, India. Biological Conservation 119: 81-92.

Page, C. 1997. Pteridophytes as field indicators of natural biodiversity restoration in the Scottish flora. Botanical Journal of Scotland 49: 37-41.

Page, C.N. 2002. Ecological strategies in fern evolution: a neopteridological overview. Review of Palaeobotany and Palynology 119: 1-33.

Patil, S., Lavate, R., Rawat, V. \& Dongare, M. 2016. Diversity and distribution of pteridophytes from Satara District, Maharashtra (India). Plant Science Today 3: 149-156.

Pausas, J.G. \& Sáez, L. 2000. Pteridophyte richness in the NE Iberian Peninsula: Biogeographic patterns. Plant Ecology 148: 195-205.

Pearson, D.L. 1994. Selecting indicator taxa for the quantitative assessment of biodiversity. Philosophical Transactions of the Royal Society of London 345: 75-79.

Poole, I. \& Page, C.N. 2000. A fossil fern indicator of epiphytism in a Tertiary flora. New Phytologist 148: 117-125.

Pos, E.T. \& Sleegers, A.D.M. 2010. Vertical distribution and ecology of vascular epiphytes in a lowland tropical rain forest of Brazil. Boletim do Museu Paraense Emílio Goeldi 5: 335-344.
Pouteau, R., Meyer, J.Y., Blanchard, P., Nitta, J.H., Terorotua, M. \& Taputuarai, R. 2016. Fern species richness and abundance are indicators of climate change on high-elevation islands: Evidence from an elevational gradient on Tahiti (French Polynesia). Climatic Change 138: 143-156.

PPG I. 2016. A community-derived classification for extant lycophytes and ferns. Journal of Systematics and Evolution 54: 563-603.

Ranieri, G. 2015. Ervas-daninhas não; plantas indicadoras! Available at http://revista.rebia.org.br/2016/89/868ervas-daninhas-nao-plantas-indicadoras (access in 23-V-2017).

Rapport, D.J. \& Hildén, M. 2013. An evolving role for ecological indicators: From documenting ecological conditions to monitoring drivers and policy responses. Ecological Indicators 28: 10-15.

Reeb, C., Ranarijaona, H.L. \& Dubuisson, J.Y. 2012. Ecological survey of the lycophytes and ferns of the Vohimana Reserve, Madagascar. Scripta Botanica Belgica 50: 73-81.

Repula, C.M.M., Quináia, S.P., De Campos, B.K., Ganzarolli, E.M. \& Lopes, M.C. 2012. Accumulation of chromium and lead in bryophytes and pteridophytes in a stream affected by tannery waste water. Bulletin of Environmental Contamination and Toxicology 88: 84-88.

Richard, M., Bernhardt, T. \& Bell, G. 2000. Environmental heterogeneity and the spatial structure of fern species diversity in one hectare of old-growth forest. Ecography 23: 231-245.

Richardson, S.J. \& Walker, L.R. 2010. Nutrient ecology of ferns. In: K. Mehltreter, L.R. Walker \& J.M. Sharpe (eds.). Fern ecology. Cambridge University Press, Cambridge, pp. 111-133.

Rocha, L.D., Costa, G.M., Gehlen, G., Droste, A. \& Schmitt, J.L. 2014. Morphometric differences of Microgramma squamulosa (Kaulf.) de la Sota (Polypodiaceae) leaves in environments with distinct atmospheric air quality. Anais da Academia Brasileira de Ciências 86: 1137-1146.

Rocha-Uriartt, L., Becker, D.F.P., Graeff, V., Koch, N.M. \& Schmitt, J.L. 2016. Functional patterns and species diversity of epiphytic vascular spore-producing plants in riparian forests with different vegetation structure from southern Brazil. Plant Ecology and Evolution 149: 261-271.

Rodríguez, J.P., Pearson, D.L. \& Barrera, R.R. 1998. A test for the adequacy of bioindicator taxa: Are tiger beetles (Coleoptera: Cicindelidae) appropriate indicators for monitoring the degradation of tropical forests in Venezuela? Biological Conservation 83: 69-76.

Romero, L.R., Pacheco, L. \& Zavala Hurtado, J.A. 2008. Pteridofitas indicadoras de alteración ambiental en el bosque templado de San Jerónimo Amanalco, Texcoco, México. Revista de Biología Tropical 56: 641-656. 
Ruokolainen, K., Linna, A. \& Tuomisto, H. 1997. Use of Melastomataceae and pteridophytes for revealing phytogeographical patterns in Amazonian rain forest. Journal of Tropical Ecology 13: 243-256.

Ruokolainen, K., Tuomisto, H., Macía, M.J., Higgins, M.A. \& Yli-Halla, M. 2007. Are floristic and edaphic patterns in Amazonian rain forests congruent for trees, pteridophytes and Melastomataceae? Journal of Tropical Ecology 23: 13-25.

Salovaara, K.J., Cárdenas, G.G. \& Tuomisto, H. 2004. Forest classification in an Amazonian rainforest landscape using pteridophytes as indicator species. Ecography 27: 689-700.

Samecka-Cymerman, A., Kolon, K., Stankiewicz, A., Kaszewska, J., Mróz, L. \& Kempers, A.J. 2011. Rhizomes and fronds of Athyrium filix-femina as possible bioindicators of chemical elements from soils over different parent materials in southwest Poland. Ecological Indicators 11: 1105-1111.

Sampson, A.W. 1939. Plant indicators - concept and status. Botanical Review 5: 155-206.

Sánchez-González, A., Zúñiga, E.A. \& Tejero-Díez, D. 2010. Richness and distribution patterns of ferns and lycopods in Los Mármoles National Park, Hidalgo, Mexico. Journal of the Torrey Botanical Society 137: 373-379.

Sathapattayanon, A. \& Boonkerd, T. 2005. Pteridophyte diversity along a gradient of disturbance within and near abandoned opencast mines in Thong Pha Phum district, Kanchanaburi province, Thailand. Fern Gazette 17: 179.

Schofield, J.E., Edwards, K.J. \& McMullen, J.A. 2007. Modern pollen-vegetation relationships in subarctic southern Greenland and the interpretation of fossil pollen data from the Norse landnám. Journal of Biogeography 34: 473-488.

Sharma, A. \& Uniyal, S.K. 2016. Heavy metal accumulation in Pyrrosia flocculosa (D. Don) Ching growing in sites located along a vehicular disturbance gradient. Environmental Monitoring and Assessment 188: 547-559.

Siddig, A.A.H., Ellison, A.M., Ochs, A., Villar-Leeman, C. \& Lau, M.K. 2016. How do ecologists select and use indicator species to monitor ecological change? Insights from 14 years of publication in Ecological Indicators. Ecological Indicators 60: 223-230.

Silva, V.L., Mallmann, I.T., Cunha, S. \& Schmitt, J.L. 2017. Impacto do efeito de borda sobre a comunidade de samambaias epifíticas em floresta com araucária. Revista Brasileira de Ciências Ambientais 45: 19-32.

Silva, V.L., Mehltreter, K. \& Schmitt, J.L. 2018. Ferns as potential ecological indicators of edge in two types of Mexican forests. Ecological Indicators 93: 669-676.

Silva, V.L. \& Schmitt, J.L. 2015. The effects of fragmentation on Araucaria forest: analysis of the fern and lycophyte communities at sites subject to different edge conditions. Acta Botanica Brasilica 29: 223-230.
Singh, H.B. 2011. Plants associated in forecasting and beliefs within the Meitei community of Manipur, Northeast India. Indian Journal of Traditional Knowledge 10: 190-193.

Smith, R.I.L. 1991. Exotic sporomorpha as indicators of potential immigrant colonists in Antarctica. Grana 30: 313-324.

Snyder, M. 2009. What are Indicator Plants? Available at http://northernwoodlands.org/articles/article/what_are indicator_plants (access in 23-V-2017).

Suganuma, M.S., de Assis, G.B., de Melo, A.C.G. \& Durigan, G. 2013. Ecossistemas de referência para restauração de matas ciliares: existem padrões de biodiversidade, estrutura florestal e atributos funcionais? Revista Árvore 37: 835-847.

Suganuma, M.S. \& Durigan, G. 2015. Indicators of restoration success in riparian tropical forests using multiple reference ecosystems. Restoration Ecology 23: $238-251$.

Szwaluk, K.S. \& Strong, W.L. 2003. Near-surface soil characteristics and understory plants as predictors of Pinus contorta site index in southwestern Alberta, Canada. Forest Ecology and Management 176: 13-24.

Tejeda-Cruz, C., Mehltreter, K. \& Sosa, V.J. 2008. Indicadores ecológicos multi-taxonómicos. In: R.H. Manson, V. Hernández-Ortiz, S. Gallina \& K. Mehltreter (eds.). Agroecosistemas cafetaleros de Veracruz. Biodiversidad, manejo y conservación. Instituto de Ecología A.C., Xalapa, \& Instituto Nacional de Ecología, México, pp. 271-278.

Traoré, D., Gu, Y., Liu, H., Shemsanga, C. \& Ge, J. 2015. Vegetation types and climate conditions reflected by the modern phytolith assemblages in the subalpine Dalaoling Forest Reserve, central China. Frontiers of Earth Science 9: 268-275.

Travassos, C.C., Jardim, M.A.G. \& Maciel, S. 2014. Florística e ecologia de samambaias e licófitas como indicadores de conservação ambiental. Biota Amazônia 4: 40-44.

Trivellone, V., Schoenenberger, N., Bellosi, B., Jermini, M., de Bello, F., Mitchell, E.A.D. \& Moretti, M. 2014. Indicators for taxonomic and functional aspects of biodiversity in the vineyard agroecosystem of Southern Switzerland. Biological Conservation 170: 103-109.

Tryon, R.M. 1972. Endemic areas and geographic speciation in tropical American ferns. Biotropica 4: 121-131.

Tryon, R.M. \& Tryon, A.F. 1982. Ferns and allied plants, with special reference to tropical America. Springer, New York.

Tuomisto, H., Moulatlet, G.M., Balslev, H., Emilio, T., Figueiredo, F.O.G., Pedersen, D. \& Ruokolainen, K. 2016a. A compositional turnover zone of biogeographical magnitude within lowland Amazonia. Journal of Biogeography 43: 2400-2411. 
Tuomisto, H. \& Poulsen, A.D. 2000. Pteridophyte diversity and species composition in four Amazonian rain forests. Journal of Vegetation Science 11: 383-396.

Tuomisto, H. \& Poulsen, A.D. 1996. Influence of edaphic specialization on pteridophyte distribution in neotropical rain forests. Journal of Biogeography 23: 283-293.

Tuomisto, H., Poulsen, A.D. \& Moran, R.C. 1998. Edaphic distribution of some species of the fern genus Adiantum in western Amazonia. Biotropica 30: 392-399.

Tuomisto, H. \& Ruokolainen, K. 1998. Uso de especies indicadoras para determinar características del bosque y de la tierra. In: R. Kalliola \& S.F. Paitán (eds.). Geoecología y desarrollo amazónico. Estudio integrado en la zona de Iquitos, Perú. Turun Yliopisto, Turku. pp. 81-491.

Tuomisto, H. \& Ruokolainen, K. 1993. Distribution of Pteridophyta and Melastomataceae along an edaphic gradient in an Amazonian rain forest. Journal of Vegetation Science 5: 25-34.

Tuomisto, H., Ruokolainen, K., Aguilar, M. \& Sarmiento, A. 2003. Floristic patterns along a $43 \mathrm{~km}$ long transect in an Amazonian rain forest. Journal of Ecology 91: 743-756.

Tuomisto, H., Ruokolainen, K., Kalliola, R., Linna, A., Danjoy, W. \& Rodriguez, Z. 1995. Dissecting amazonian biodiversity. Science 269: 63-66.

Tuomisto, H., Ruokolainen, K., Poulsen, A.D., Moran, R.C., Quintana, C., Canas, G. \& Celi, J. 2002. Distribution and diversity of pteridophytes and Melastomataceae along edaphic gradients in Yasuni National Park, Ecuadorian Amazonia. Biotropica 34: 516-533.

Tuomisto, H., Ruokolainen, K., Vormisto, J., Duque, A., Sánchez, M., Paredes, V. V. \& Lähteenoja, 0. 2016b. Effect of sampling grain on patterns of species richness and turnover in Amazonian forests. Ecography 40: 840-852.
Turner, J.B. \& McGraw, J.B. 2015. Can putative indicator species predict habitat quality for American ginseng? Ecological Indicators 57: 110-117.

Turnhout, E., Hisschemöller, M. \& Eijsackers, H. 2007. Ecological indicators: Between the two fires of science and policy. Ecological Indicators 7: 215-228.

Vormisto, J., Phillips, O.L., Ruokolainen, K., Tuomisto, H.\& Vasquez, R. 2000. A comparison of fine-scale distribution patterns of four plant groups in an Amazonian rainforest. Ecography 23: 349-359.

Watson, L.H. \& Cameron, M.J. 2002. Forest tree and fern species as indicators of an unnatural fire event in a southern Cape mountain forest. South African Journal of Botany 68: 357-361.

Williams-Linera, G., Palacios-Rios, M. \& HernándezGómez, R. 2005. Fern richness, tree species surrogacy, and fragment complementarity in a Mexican tropical montane cloud forest. Biodiversity and Conservation 14: 119-133.

Williams, P.H. \& Gaston, K.J. 1994. Measuring more of biodiversity: Can higher-taxon richness predict wholesale species richness? Biological Conservation 67: 211-217.

Wolff, G., Pereira, G.C., Castro, E.M., Louzada, J. \& Coelho, F.F. 2012. The use of Salvinia auriculata as a bioindicator in aquatic ecosystems: biomass and structure dependent on the cadmium concentration. Brazilian Journal of Biology 72: 71-77.

Young, K.R. \& Léon, B. 1989. Pteridophytes species in the central Peruvian Amazon: Importance of edaphic specialization. Brittonia 41: 388-395.

Zuquim, G. 2015. Ferns and lycophytes in Amazonia: Diversity patterns and usefulness as habitat indicators. University of Turku, Turku.

Zuquim, G., Tuomisto, H., Jones, M.M., Prado, J., Figueiredo, F.O.G., Moulatlet, G.M., Costa, F.R.C., Quesada, C.A. \& Emilio, T. 2014. Predicting environmental gradients with fern species composition in Brazilian Amazonia. Journal of Vegetation Science 25: 1195-1207. 